\title{
Integrated analysis of risks of coastal flooding and cliff erosion under scenarios of long term change
}

\section{Short title: Integrated analysis of coastal risks}

R. J. Dawson (author for correspondence) $)^{1,11}$, M. E. Dickson ${ }^{2}$, R. J. Nicholls ${ }^{3,11}$, J. W. Hall ${ }^{1,11}$, M. J. A. Walkden ${ }^{1,11}$, P. Stansby ${ }^{4,11}$, M. Mokrech ${ }^{3,11}$, J. Richards ${ }^{6,11}$, Jianguo Zhou ${ }^{7}$, J. Milligan ${ }^{5,11}$, A. Jordan $^{5,11}$, S. Pearson ${ }^{8}$, J. Rees ${ }^{9}$, P. Bates ${ }^{10}$, S. Koukoulas ${ }^{11}$, A. Watkinson ${ }^{5,12}$.

1. School of Civil Engineering and Geosciences, Newcastle University, Newcastle upon Tyne, NE1 7RU, UK.

2. School of Geography, Geology and Environmental Science, The University of Auckland, Private Bag 92019, Auckland, New Zealand.

3. Southampton University, School of Civil Engineering and the Environment and the Tyndall Centre for Climate Change Research, Highfield, Southampton SO17 1BJ, UK.

4. School of Mechanical, Aerospace and Civil Engineering, University of Manchester, Manchester M60 1QD, UK.

5. School of Environmental Sciences, University of East Anglia, Norwich, NR4 7TJ, UK

6. ABP Marine Environmental Research, Waterside House, Town Quay, Southampton, S014 2AQ, UK.

7. Department of Civil Engineering, University of Liverpool, Brownlow Hill, Liverpool, L69 3GH.

8. British Geological Survey, Keyworth, Nottingham, NG12 5GG, UK.

9. Natural Environment Research Council, Polaris House, North Star Avenue, Swindon, SN2 1EU.

10. School of Geographical Sciences, University of Bristol, University Road, Bristol. BS8 1SS, UK.

11. University of the Aegean, Geography Dept., University Hill, Mytilene 81100, Greece.

12. Tyndall Centre for Climate Change Research.

Address and contact details for correspondence:

Dr. Richard Dawson

School of Civil Engineering and Geosciences,

Room 3.21: Cassie Building,

Newcastle University,

Newcastle upon Tyne, NE1 7RU, UK.

Tel: +44(0)1912226618

Fax: +44(0)191222 6502

Email: richard.dawson@newcastle.ac.uk 


\begin{abstract}
The risks to human populations in coastal areas are changing due to climate and socio-economic changes, and these trends are predicted to accelerate during the $21^{\text {st }}$ Century. To understand these changing risks, and the resulting choices and pathways to successful management and adaptation, broad-scale integrated assessment is essential. Due to their complexity these two risks are usually managed independently, yet frequently they are interconnected by longshore exchange of sediments and the resulting broad scale morphological system behaviour. Simply put, if beach levels rise or fall, flood risk in adjacent low-lying coastal areas decreases or increases respectively. In order to generate new insights into the effects of climate change and coastal management practises on coastal erosion and flood risk, we present an integrated assessment of $72 \mathrm{~km}$ of shoreline over the $21^{\text {st }}$ Century on the East Anglian Coast of England. A coupled system of hydrodynamic, morphological, reliability and socio-economic models has been developed for the analysis, which has been implemented under scenarios of climate and socio-economic change. The study is unique in coastal management terms because of the large spatial scale and extended temporal scales over which the analysis is quantified, but is also a site of significant controversy about how to manage coastal flood and erosion risks over the $21^{\text {st }}$ Century. This study for the first time quantifies what has for some years been argued qualitatively: the role of sediments released from cliff erosion in protecting neighbouring low-lying land from flooding. The losses and benefits are expressed using the common currency of economic risk. The analysis demonstrates that over the $21^{\text {st }}$ Century, flood risk in the study area is expected to be an order of magnitude greater than erosion risk. Both climate and socio-economic change can have a significant influence on flood risk. This study demonstrates that the choices concerning coastal management are profound, and there are clear tradeoffs between erosion and flood impacts.
\end{abstract}




\section{Introduction}

Climate change with its associated rising sea level, and possible increases in the frequency and/or the intensity of storms and changes in wave climate can be expected to increase the risks of coastal erosion and flooding in most coastal locations (Nicholls et al., 2007a). Changes in the pattern and extent of coastal erosion and flooding are all the more concerning because a significant proportion of the world's population reside in the coastal zone: in 1990, 1.2 billion people lived in the nearcoastal zone (the area both within $100 \mathrm{~km}$ distance of the coast and $100 \mathrm{~m}$ elevation of sea level) at densities about three times the global mean (Small and Nicholls, 2003). Urbanisation has resulted in a high concentration of the world's cities and settlements (Nicholls, 1995; Small and Nicholls, 2003) and a considerable portion of global GDP being produced in coastal zones (Turner et al., 1996; Nordhaus, 2006). GDP and population density in the coastal zone are higher than the global average. These socio-economic and demographic trends often imply growth in flood and erosion risk areas, compounding the increase in risk due to climate change. Successful management of the coastal zone has consequently been identified as a major challenge for the $21^{\text {st }}$ Century (Sciberras, 2002). However, integrated analysis of environmental and social change on the coast includes major uncertainties due to the many complex and interacting variables. In the face of these uncertainties, coupled scenarios of climate change projections and socio-economic change have been used to construct a number of alternative futures and to gain a broad appreciation of the scale of future flood and erosion risks that may need to be addressed (c.f. Parry, 2004; Holman et al., 2005; Thorne et al., 2007).

It is fundamental to recognise that there is a longshore connectivity between the various geomorphological features that comprise the natural coastal system, as recognised in the concept of littoral cells and sub-cells (Komar, 1998; Leafe et al., 1998). Hence, evolution of one length of coastline influences the evolution in morphologically-connected areas. This sediment movement along beaches and in shallow coastal waters provides a mechanism of interaction between erosion processes and flood risk. The behaviour of beaches is a key determinant of flood risk. Beach morphology has a critical role in dissipating incident wave energy. Moreover, on natural coasts, the beach is the 'defence', while on artificially managed coasts the reliability of structures usually depends on beach volume as the level of the adjacent beach influences the likelihood of toe scour, a critical failure mechanism for coastal structures. Sediments released from erosion may serve to increase beach volume and reduce the probability of structural failure on neighbouring coasts. Conversely, the existence of structures that disrupt sediment movement may starve down-drift beaches of much needed beach protection. Therefore, coastal managers should no longer consider 
erosion and flood hazards in isolation. Rather analysis of climate impacts and long term coastal management must be implemented at an appropriate (broad) scale to account for this morphological interdependence.

Thus, there is a need for a systematic and integrative approach to analyse the impact of long term change on both coastal flood risk and coastal erosion. Risk assessment provides a rational basis for supporting the development of coastal management policy, allocation of resources and monitoring the performance of coastal management activities on local, regional and national scales. Estimates of risk, expressed in terms of expected annual damages, provides a common currency with which erosion impacts can be compared with flood impacts. Furthermore, in a situation where there are several organisations responsible for coastal management, as is the case in many countries, quantified risk analysis helps identify the organisation(s) most able to mitigate the risk.

Approximately 3\% of the land area of England and Wales is at risk from coastal flooding. Similar to global patterns, this relatively small area is highly developed, containing over 1million residential and non-residential properties with expected annual damages to property of $£ 1.0 \mathrm{bn}$ and lost agricultural production worth $£ 5.9 \mathrm{~m}$ (Hall et al., 2006). In addition to the risk of flooding in coastal lowlands, of the 3,700 km coastline of England and Wales, 28\% is experiencing erosion greater than 10 centimetres a year (Burgess et al., 2007), despite the existence of coastal protection structures along more than $60 \%$ of this coastline (Eurosion, 2004).

In this paper, we describe the application of risk analysis under scenarios of future climate and socio-economic change to analyse alternative coastal management options on a $72 \mathrm{~km}$ stretch of UK coastline that has experienced flooding and cliff erosion for many centuries. This integrated assessment allows us to explore the effects of (1) a range of climate change factors, particularly (a) sea-level rise, (b) wave height, and (c) wave direction, (2) different coastal defence management choices, and (3) socio-economic development, on the evolution of flood and erosion risk. Whilst the concept of integrated assessment of coastal risks is not new (Holman et al., 2002; Hall et al., 2005), this analysis is notable in its deployment of physically-based models over such a large spatial scale and over extended timescales. The analysis has consequently enabled the quantified assessment of the feedbacks between different coastal hazards under a number of different scenarios of change. We begin with a description of the study site followed by the risk analysis framework and a description of each of the components in the coupled system of models used to conduct the assessment. 


\section{Study domain and management challenges}

\section{$2.1 \quad$ The coastline}

The case study site is a $72 \mathrm{~km}$ length of coastline and hinterland between Weybourne and Lowestoft on the east coast of England (Figure 1). It is designated as a 'coastal sub-cell' (number 3b) in UK coastal management planning, which means that it is reasonably self-contained in terms of sedimentary interactions with neighbouring coastlines (DEFRA, 2006). The north of the site, between Weybourne and Happisburgh, is comprised of retreating chalk and till cliffs, whereas the southern area of the site between just south of Happisburgh and Great Yarmouth is generally low lying and at risk of coastal flooding, although there are some areas of raised ground and local cliffs between Winterton Ness and Great Yarmouth, and South of Breydon Water and Lowestoft as shown in Figure 1.

Figure 1 Location of the study area in eastern England, showing the location of the major settlements and land elevation. The area of cliff erosion is indicated by the dotted line.

Between Weybourne and Cromer, there is a transition in cliff geology from predominantly chalk to predominantly till. Coincidentally, in this general area there is also a divide in the direction of longshore sediment transport such that sediment is transported westwards, west of Cromer and eastwards east of Cromer (Vincent, 1979; Clayton, 1989), as well as a change in the size of beach sediments (Chang and Evans, 1992). Beaches south of Cromer are predominantly sandy with pebbles present in varying proportions whereas beaches in front of the north-facing chalk cliffs have an increasingly high proportion of pebbles from Cromer through to Weybourne where beaches are composed largely of pebbles. Clayton (1989) estimated that the glacial-till cliffs have retreated at rates averaging around $1 \mathrm{~m}$ per year over some 5000 years, whereas the chalk cliffs have retreated somewhat slower.

The major settlements of Sheringham, Cromer and Mundesley have been protected with groynes and seawalls since the latter part of the 19th Century, with Overstrand similarly protected excepting the construction of a seawall and additional groynes in early and mid 20th Century. South of Mundesley towards Happisburgh most major coastal engineering works occurred between 1950 and 2000, with construction mainly comprising groynes and palisades many of which are now nearing the end of their effective life. 
The coast south-east of Happisburgh includes large areas of low-lying land in the Norfolk Broads (from Eccles to Winterton) and smaller areas at Great Yarmouth and Lowesoft (Figure 1). Much of this low-lying hinterland is reclaimed marshland and is below the level of mean high water spring tides and therefore highly susceptible to flooding. Extensive flooding of the Broads area within sub-cell 3b has occurred a number of times over the last 100 years, most notably in 1907, 1938, 1953 and 1978 (Mosby, 1938; Steers, 1953; Grieve, 1959; Harland and Harland, 1980): in the 1953 flood 17 people died in sub-cell 3b (Kelman, 2003). An extensive system of dunes has been reinforced by construction of seawalls and groynes. In the 1990s the progressive lowering of the beaches in front of these structures near Sea Palling, and consequent increase in flood risk, was addressed by construction of nine detached breakwaters and extensive beach nourishment (Thomalla and Vincent, 2006). The dunes south-east of Happisburgh are protected by concrete seawalls (Figure 2) with a combined height of more than $10 \mathrm{~m}$ high along most of this stretch of coastline.

Figure 2 Beach at Winterton with concrete sea wall in front of sand dune on $31^{\text {st }}$ October 2003 (the detached breakwaters are just visible on the horizon)

Further south at Winterton the beaches are wider with timber groynes and there is a more extensive dune system. South again at Great Yarmouth, areas of land are sufficiently low to have been inundated during previous extreme events, such as the 1953 flood. Failure, through undermining or wave overtopping of the structures protecting the promenade of Great Yarmouth, is unlikely to lead to inundation due to the relative level of the hinterland. However, wave overtopping and overflow of the harbour walls at Great Yarmouth are more likely and extreme sea levels in the tidal flats of Breydon Water could result in inundation in areas of Great Yarmouth, such as Southtown (as occurred in 1953). South of Great Yarmouth, and just North of Lowestoft, there are four sections of seawall, totalling $2.3 \mathrm{~km}$ in length, with a crest height of $5-5.5 \mathrm{~m}$. The seawall is fronted by a sand/shingle foreshore for $1.7 \mathrm{~km}$ and rock armour for a length of $600 \mathrm{~m}$. The defences protect a small area of low lying land whose main economic assets are caravan parks.

\subsection{Vulnerability to coastal risks}

There are currently almost 20,000 properties at risk of coastal flooding in the model domain, over 3,000 of which are non-residential. Almost $50 \%$ of the floodplain, which is almost $340 \mathrm{~km}^{2}$, is premium agricultural land, with only 5\% less productive agricultural land (Figure 3). Some 35\%, is registered as being environmentally sensitive (with Sites of Special Scientific Interest, Ramsar, 
salt marsh, national nature reserve designations). Along the $32 \mathrm{~km}$ stretch of eroding coastline there are almost 1,400 properties within $100 \mathrm{~m}$ of the cliff top. Of this area, $37 \%$ is premium agricultural land and a further $50 \%$ is less productive agricultural land.

The study area has a long history of erosion and flooding, but climate change exacerbates both these risks in terms of loss of buildings on the cliff coast and increased flood risk in the coastal lowlands. Erosion risk if exacerbated by trends for increased building in these areas, although planning regulations for cliff top areas do take specific account of risks associated with coastal erosion (NNDC, 2006). At the national scale, a recent planning policy statement (DCLG, 2006) provides guidance on floodplain development. A new shoreline management plan for sub-cell 3b (Halcrow et al., 2006), which has not yet been adopted, has proposed abandoning significant lengths of cliff defences over the next few decades, which would result in increased loss of cliff-top buildings. Happisburgh exemplifies this strategy: it was deemed uneconomic to renew the existing defences which fell in to disrepair following storms in 1991 and 1996, and after becoming a threat to public safety were subsequently removed. The shoreline response to the collapse of the defences was rapid with short-term retreat rates of up to $10 \mathrm{~m}$ /year and the loss of 26 houses from 1992-2007 and other properties evacuated. Consequently, citizen groups have formed, who with the local council have started a fund for rocks for cliff protection, and Happisburgh has been the subject of national attention.

Figure 3 Land use and location of settlements (Grades correspond to those in Table 3)

\subsection{Management options}

The UK government has been promoting a strategic approach to coastal management through the use of Shoreline Management Plans (SMPs) (Leafe et al., 1998; Cooper et al., 2002; DEFRA, 2006) and more detailed local coastal strategy plans. These plans take a strategic view of coastal processes and associated risks over extended timescales (up to 100 years). A broad range of options, including managed retreat of the coastline as well as measures to prevent erosion and flooding are considered.

Within this paper, we consider a wide range of contrasting cliff erosion management scenarios ranging from a highly artificial state in which the whole coast is permanently protected with a seawall (Scenario A), through to full abandonment for which all structures are removed (Scenario E). Intermediate management scenarios, that correspond closely to suggested strategies (c.f. Halcrow et al., 2006) include those where some form of coastal defence (seawall, groynes, or 
palisades) is maintained along about 71\% (the current state, Scenario B), 34\% (Scenario C), and $16 \%$ (Scenario D) of the cliffed coast. Where removal of coastal structures is simulated it is assumed to happen in a realistic manner, such that structures are removed first from areas with the lowest economic value and at the end of their expected lives, which is generally before 2030 .

For this study, the flood defence structures are assumed to be maintained at their current crest level and condition. This enables the impact of strategic shoreline management decisions for the cliffed section of coast to be explored, as it enables changes to flood risk to be measured directly against a baseline scenario. Flood management options, which are not considered in this paper, include raising flood defences, adding sediment trapping structures (groynes, detached breakwaters etc.) and beach recharge - many of these options are already ongoing. Although these are likely responses to a number of climate scenarios considered here, in the absence of more detailed analysis of the costs of such works there are few insights to be gained from analysis of scenarios of improving the flood defence system. More radical flood management options include a proposal to realign the flood defences such that approximately 6,500ha of land are completely inundated or converted into inter-tidal habitat forming a new estuary (English Nature et al., 2003).

\section{Assessment methodology}

The assessment has been conducted with a coupled system of hydrodynamic, morphological and impacts models, as illustrated in Figure 4. These models were used in a baseline assessment of the risk in 2003 and then modified to include scenarios of:

- climate change;

- demographic and economic change; and

- shoreline management options,

implemented separately and/or in combinations. First we discuss the probabilistic framework for estimating the risks of coastal erosion and coastal flooding, before examining each of the main steps in the modelling process (Figure 4) in more detail.

Figure 4 Overview of the assessment methodology, including the role of the scenarios

\subsection{Risk analysis framework}

The occurrence of damaging erosion or flooding on the coast is determined by highly variable marine processes (surge tides, extreme waves) and the (uncertain) responses of the coastal system. 
It is therefore impossible to predict coastal flooding and erosion in deterministic terms. Instead, a risk-based approach is adopted in which coastal behaviour is predicted, through time, in probabilistic terms and combined with assessment of impacts in order to quantify the 'expected annual damage'. The primary metric for comparison of scenarios and management options here is economic risk, but this can be supplemented by indicators of potential social or environmental impact if available.

Spatial distribution of risk is defined relative to a baseline roughly parallel to the coast. Distances inland from the baseline are designated as the $x$ direction and distances up and down the coast are designated the $y$ direction. The probability of the damaging event, be it due to coastal erosion or flooding, is represented by a function, which will in general vary over space $x \times y$ and time $t$. The consequences of damaging events will in general depend on its magnitude and will also vary over space and time. Thus, in general, the risk at a particular point in time can be written as the product of probability (obtained by integrating over the relevant probability density functions) and consequences. We consider two risks:

(i) erosion risk, which is calculated by combining probabilistic cliff top erosion predictions with maps of the location of coastal properties, modified as necessary to represent future economic and land use changes;

(ii) flood risk, which is calculated by combining annual probabilities of flooding with maps of the location of properties in the coastal floodplain, modified as necessary to represent future economic and land use changes.

\subsubsection{Erosion risk}

Erosion of the material from the foot of a coastal cliff or bluff will steepen the cliff. Eventually, erosion will lead to a landslide collapse of the cliff top and a consequent reduction in the cliff slope. The recession process proceeds at an irregular rate through occasional landslide events. Generally recession involves small-scale failures, but occasionally large-scale failures do occur, as seen at Overstrand in 1990, 1992 and 1994 (Frew and Guest, 1997).

The morphological modelling described below is used to predict shoreline (i.e. cliff toe) location, $x_{s}(y, t)$ at distances $y$ along a shore-parallel baseline and time $t$ years in the future. This prediction includes the effects of natural variability in the environmental forcing (waves and tides) and is conditional upon a particular climate scenario. Given a particular shoreline location, $x_{s}$, we then generate a probability density function (p.d.f.), $f_{c}\left(x \mid x_{s}, y, t\right)$ of the cliff top location, $x$, at a distance $y$ 
along the coast and in year $t$ using the method described by Hall et al. (2000). This p.d.f. expresses the uncertainty in the location of the cliff top, relative to a given shoreline. The expected annual damage due to erosion, $r_{c}$, is therefore given by:

$r_{c}(t)=\iint f_{c}\left(x \mid x_{s}, y, t\right) c_{c}(x, y, t) d x d y$

where $c_{c}(x, y, t)$ is a spatially variable damage function constructed from market values of property and agricultural land, which will depend upon the socio-economic scenario (c.f. Thorne et al., 2007).

\subsubsection{Flood risk}

In calculating flood risk we consider the following causal sequence:

(i) Shoreline morphology change raises and lowers beach levels in front of flood defence structures.

(ii) The arrival of an extreme storm causes overtopping and/or breaching of flood defence structures, which may already be weakened by the long term recession processes described in (i).

(iii) Water that passes the flood defences due to overtopping or breaching causes temporary inundation of the coastal floodplain.

(iv) Damage is caused to coastal residents and properties that are flooded, the severity of which increases with flood depth.

The failure of the flood defence system is dealt with via a simplified reliability analysis (see Dawson and Hall, 2006). The flood defence system is considered to be comprised of $n$ components each of which may be a 'failed' or 'non-failed' state. There are therefore $2^{n}$ combinations of failure and non-failure, which are labelled $S_{i}: i=1, \ldots, 2^{n}$. The response of the flood defence system to environmental loading (i.e. wave heights, $h$, and water levels, $w$ ) is described in terms of a 'fragility function' (Dawson and Hall, 2006), $P\left(S_{i} \mid H, W, x_{S}\right)$, which is the conditional probability of the system being in state $S_{i}$, given wave height, $H$, water level, $W$, and shoreline location $x_{s}$. The flood risk is therefore calculated according to the following expression:

$r_{f}(t)=\iint \sum_{i=1}^{2^{n}} P\left(S_{i} \mid H, W, x_{s}\right) f_{f}(H, W \mid t) c_{f}\left(H, W, S_{i}, t\right) d H d W$ 
where $f_{f}(h, w \mid t)$ is the joint probability density function of wave height, $h$, and water level, $w$, at time $t$. Dependence upon $t$ reflects the fact that the frequency of waves and extreme water levels (due to sea-level rise) is expected to change with climate change. $c_{f}\left(h, w, S_{i}, t\right)$ is a damage function, which:

- for a given combination, $S_{i}$, of flood defence failures, wave height $h$ and water level $w$, uses hydrodynamic inundation modelling to calculate flood depths in the floodplain, and

- uses information on the location of properties, together with standard depth-damage functions (Penning-Rowsell et al., 2005) to calculate the flood damage.

Note how the causal sequence described above is reflected in Equation 2:

(i) Shoreline recession, $x_{s}$, is reflected in the probability of failure of the flood defence structures, $P\left(S_{i} \mid H, W, x_{S}\right)$.

(ii) The arrival of an extreme storm is described by the joint probability density function $f_{f}(H, W \mid t)$ and may cause failure of one or more of the defences structures, depending upon the conditional probability $P\left(S_{i} \mid H, W, x_{S}\right)$.

(iii) The severity of flood inundation depends upon the environmental loading conditions, $h$ and $w$, and the number and locations of flood defence failures, which are reflected in $c_{f}\left(H, W, S_{i}, t\right)$.

(iv) The damage to properties located in the floodplain, for a given flood depth, is also reflected in $c_{f}\left(H, W, S_{i}, t\right)$. As with cliff erosion, the function $c_{f}\left(H, W, S_{i}, t\right)$ changes through time to reflect changing land use and socio-economic exposure in the floodplain.

Note that where $n$ is large it is intractable to solve Equation 2 precisely so an importance sampling approach, described in Dawson and Hall (2006), has been employed. The total risk $r(t)$ at time $t$ is simply the sum of the cliff erosion and flood risk:

$r(t)=r_{c}(t)+r_{f}(t)$

The various statistical and process-based models that generate predictions of the variables in Equations 1 and 2 are now described.

\subsection{The environmental forcing: waves and tides}

The coast is exposed to waves generated within the North Sea from directions between approximately $330^{\circ} \mathrm{N}$ and $120^{\circ} \mathrm{N}$, but the largest waves arrive from the North through to the East where fetch lengths exceed $500 \mathrm{~km}$. The most frequent waves are from the northwest. Estimates of extreme water levels corresponding to different return periods are shown in Table 1.

Table 1 Return periods for extreme water levels (mAOD) at Cromer and Great Yarmouth (Dixon and Tawn, 1997) 
The morphological modelling described below is driven by water levels and wave heights at tidal timesteps. Records of water levels were available for Cromer from 1988-2002. These were extended to generate a stationary synthetic time series of 1000 years by resampling segments, whilst preserving seasonality. Extreme values were re-sampled from a distribution that was constructed using estimates of extreme water levels provided by Dixon and Tawn (1997). Wave heights were hindcast from 23 years of wind data (from 1978-2001) and extended to 1000 years (HR Wallingford, 2002). This long record was constructed from month segments resampled from the original 23 year file, preserving seasonality. A distribution was fitted to extreme values and used to resample extreme events in the long synthetic series. The length of this time series was dictated by the long initialisation period of the morphological model (see Walkden and Hall, 2005). Subsequently a time series to represent changing climatic conditions over the timescale 2000-2100 was developed for prediction runs of the morphological model as described below.

\subsection{Future marine climate}

Three representative relative sea-level rise scenarios were used which were designed to encompass the range of uncertainty in global, regional and local sea levels. This is mainly based on the Intergovernmental Panel on Climate Change (IPCC) Third Assessment Report (Church et al., 2001) and the related UK Climate Impacts Programme (UKCIP02, Hulme et al., 2002). The 'low' scenario of relative sea level rise (RSLR) represented no anthropogenic influence, i.e. a continuation of the recent historic rate of $1.5 \mathrm{~mm} \mathrm{yr}^{-1}$ (see also Miller and Douglas, 2004). The 'medium' scenario follows the UKCIP02 medium-high scenario and results in a $21^{\text {st }}$ Century increase of $0.45 \mathrm{~m}$ by 2100 . The 'high' scenario is based on the IPCC high limit plus an additional regional (North Atlantic scale) sensitivity of 50\% (following Hulme et al. (2002)) to allow for spatial variability in thermal expansion (see Gregory et al., 2001). This scenario results in an increase in sea level of $1.2 \mathrm{~m}$ by 2100 . All three sea level rise scenarios used include a regional subsidence rate based on long-term geological observations of $0.7 \mathrm{~mm} \mathrm{yr}^{-1}$ (Shennan and Horton, 2002).

Long term predictions of changes in wind, and hence wave, speed and direction from climate models are considered to be very uncertain. However, climate model predictions are supported by observations in the North Sea and Atlantic Ocean, which suggest that extreme wave heights may be increasing (Bouws et al., 1996, Kushnir et al., 1997). Given the concern about increasing wave heights, the sensitivity of erosion and flood risk to a range of possible future conditions rather than downscaling climate model outputs directly was explored. Wave heights were unchanged in the 
'low' scenario, whereas in the 'medium' and 'high' scenarios offshore winter wave heights were increased up to a maximum of $7 \%$ and $10 \%$ respectively by 2100 . These increases were applied linearly over the $21^{\text {st }}$ Century. In addition, the 'high' scenarios included $+10^{\circ}$ (clockwise) and $-10^{\circ}$ (anticlockwise) rotations of the offshore wave rose. Potential changes to wave period were not considered.

It was not feasible to test all the combinations of sea-level rise, wave height and wave direction scenarios together with all the management options mentioned in Section 2.3 above. Therefore, there was a deliberate focus on the low and the high scenarios of relative sea-level rise, to provide bounds on the potential future outcomes. Table 2 summaries the combinations of scenarios and management options that were tested in the coupled analysis. A range of behaviour is noted in the different scenarios. Those we explore in this paper are highlighted in Table 2. Those that also consider socio-economic change use the same numbering scheme, but prefixed by WM, GS, LS, NE to correspond to the World Markets, Global Sustainability, Local Stewardship and National Enterprise socio-economic scenarios respectively (see Section 3.10).

Table 2 Scenario numbering scheme for the coastal management and climate change combinations considered in this study. ' + ' and '-' indicate rotation of the wave rose by 10 degrees clockwise and anticlockwise respectively; percentages indicate proportions of cliffed coast protected by structures.

The italicised scenarios are those that are explored in more detail in this paper.

\subsection{Wave propagation modelling}

Propagation of waves from deep water off the coast of East Anglia over the complex bathymetry to the boundary of the morphological model was conducted with the TOMAWAC code (part of the Electricité de France TELEMAC suite) (Kuang and Stansby, 2004, Stansby et al., 2006) over an area of approximately $75 \mathrm{~km} \mathrm{x} 100 \mathrm{~km}$ (Figure 5). The model operates on an unstructured (finiteelement) grid which may adapted to give high resolution where needed and accounts for shoaling, refraction, dissipation by whitecapping, bed friction and depth-limited breaking and wave-wave energy transfers, but does not consider diffraction. The analysis for long-term predictions, involving domain calibration described below, is based upon the assumption that wave propagation inshore is not affected significantly by tidal (or wave-induced) currents, directionality (whether broad or narrow), and wave generation within the coastal domain. This has been previously justified for this area (Kuang and Stansby, 2004), although very high wind speeds (greater than about 20m/s) may modify the wave transformation somewhat. The offshore wave climate was obtained from onshore 
wind data assuming a long fetch with an unchanging wind direction, applying formulae for significant wave height and period from the Shore Protection Manual. This simplistic approach enabled historical predictions of cliff erosion from 1885 to be undertaken with reasonable success. Furthermore, it has been assumed that the bathymetry of the site remains constant. This is a significant assumption as the shallow sandbanks within the model domain (Figure 5) are mobile and major changes have been observed over timescales of decades and centuries. Since both sea level rise and sandbank erosion will result in greater depths, greater inshore wave heights will result and the present approach will underestimate shoreline erosion.

Figure 5 Wave transformation modelling domain showing the bathymetry (metres below Ordnance Datum) off the East Anglian coastline

Long-term nearshore wave climate data resulting from the hourly time series for offshore conditions were required for the morphological model (introduced in the following section). Processing the entire time series for a period of 100 years would have involved about $10^{6}$ TOMAWAC runs each taking about 30 minutes. Instead, 500 combinations, covering the full range of the parameter space, of offshore wave height, period and direction were simulated and used to construct curves from which the remaining nearshore wave conditions could be interpolated without re-using TOMAWAC (Stansby et al. 2006) enabling nearshore wave climate time series to be generated in minimal computer time. Predictions of wave conditions inshore from the curves were compared with measurements made by the Environment Agency in 2002-03, and nearshore wave height was predicted with little error, wave period was rather more scattered and wave direction was not recorded by these measurements so could not be compared. The calibration process is described in full by Stansby et al. (2006).

\subsection{Long term coastal morphological modelling}

The effect of waves and tides on littoral sediment transport and erosion of the soft coastal cliffs and platform was simulated using the SCAPE model (Walkden and Hall, 2005, Dickson et al., 2007). SCAPE represents a number of processes and their interactions:

- Wave transformation from the nearshore points provided by the TOMAWAC model to the breaker point using linear wave theory.

- Sediment exchange between the beach and a nearshore bar using a simple parameterization of the COSMOS model (Nairn and Southgate, 1993).

- Longshore sediment transport using a one-line beach model (Pelnard-Considere, 1956) of the form described in the Shore Protection Manual (CERC, 1984). 
- $\quad$ Erosion of the shore platform and cliff toe (Walkden and Hall, 2005).

- Delivery of talus to the beach.

- The effect of shore parallel coastal structures (seawalls and palisades) and groynes as follows: (1) seawalls prevent cliff toe retreat, but do not stop lowering of the shore platform, (2) palisades reduce the heights of passing waves by 50\%, and (3) groynes reduce longshore sediment transport, except when beaches are wider than the structures.

This paper extends the SCAPE model to represent cliff failure and retreat of the cliff top (Hall et al., 2000). The shape of the coast, in both profile and plan-view, emerges from the dynamic interaction between and within modules, which respond to the imposed loading (waves, tides and SLR) and coastal management interventions. After simulating the construction of coastal engineering structures between the later part of the 1800s and 2000, model behaviour was compared with historical recession data measured from Ordinance Survey maps. Once a satisfactory validation was achieved (described fully in Dickson et al. 2007), the model was run under combined climatechange and management scenarios for the $21^{\text {st }}$ Century.

\section{Figure 6 Location of SCAPE model sections for simulating the long term morphological response of the coast illustrating the major morphological features}

The southern part of the SCAPE model (Figure 6) includes the low-lying coast between Happisburgh and Winterton, an area with no cliff, a low platform and a deep sandy beach. The absence of a cliff/platform means that all the beach sediment in this section arrives through easterly longshore transport. Consequently the beach volume and berm levels here ultimately depend on patterns of sediment supply and longshore transport from the cliffed coast South of Sheringham. For this reason, shoreline management decisions to prevent cliff recession or to construct groynes cause the southern beaches to denude, whilst the removal of existing structures releases sediment that increases the beach volume.

The beach component in the SCAPE model has been extended south of the soft cliffs to the lowlying coast as far as Winterton Ness. South of the drift divide at Winterton Ness the land rises above typical flood levels and is not at significant risk of flooding (Figure 1). The main flood protection structures are in the Great Yarmouth and Lowestoft harbours and tidal river reaches. However, a small area of floodplain exists at Lowestoft Denes (just north of Lowestoft), and in parts of the town itself, although in all this section is significantly less important in terms of impacts. The influence of cliff management on this region is less significant as for the Happisburgh to Winterton section due to offshore losses of sand to nearshore banks and the presence of several 
barriers to longshore transport (for example, the estuary and associated harbour breakwaters at Great Yarmouth) (Futurecoast, 2002). Moreover, the SCAPE model is most rationally deployed where there is significant interaction between cliff and beach and so a simplified approach based on the Bruun rule was applied (described by Bruun (1962) and many others), using past observations for calibration (Halcrow, 1999, Futurecoast, 2002), to provide an estimate of shoreline recession. This means that the probability of failure due to toe erosion (and overtopping) is only influenced by changing sea level and wave conditions, with no longshore interaction.

\subsection{Cliff failure modelling}

For economic appraisal of the impacts of coastal cliff recession, predictions are required of when individual cliff-top assets will be lost due to coastal landsliding. Coastal landsliding is a consequence of a combination of cliff toe recession and geotechnical processes within the cliff slope. Landsliding on unprotected soft cliffs is preceded by a process of marine removal of material from the cliff toe, resulting in steepening of the coastal slope. Eventually the slope becomes unstable and a landslide occurs that reduces the coastal slope and delivers debris to the beach. The timing of the landslide is a function of the rate of removal of material from the cliff toe and other processes, primarily connected with pore pressure distributions within the cliff that influence cliff stability. The timing of a landslide cannot be predicted precisely. However, knowledge of the rate of shoreline retreat (from SCAPE) can be combined with an assessment of the geotechnical characteristics of the slope to generate an approximate probability distribution of the possible cliff top location following failure (Hall et al., 2000).

The approach adopted here is based on the notion of a Cliff Behavioural Unit (CBU) as being a stretch of cliff-line which behaves in broadly the same way. Within a CBU, the cliff can be expected to fail when it reaches an average angle $\alpha_{f}$ and will, after failure, adopt an angle $\alpha_{s}$. Neither $\alpha_{f}$ nor $\alpha_{s}$ can be predicted precisely. They will vary because of temporal variations in pore pressure and local variations in cliff strength and composition. Even if all the required information were available, they could still not be predicted precisely because of uncertainties in our understanding of the processes of coastal landsliding. This uncertainty in $\alpha_{f}$ and $\alpha_{s}$ has been included in the analysis by representing both values as Normally-distributed random variables, with means and variances obtained from a geomorphological assessment of the CBU. The situation is illustrated diagrammatically in Figure 7. 
Figure 7 Diagrammatic representation of the coastal landsliding model. The parameters are described in the text.

Further uncertainty is apparent in the initial cliff angle at the site. Within a CBU there will be a range of initial angles, whilst in this analysis (other than for very long CBUs) a prediction of cliff top recession has been generated for entire CBUs or, where appropriate, sub-sections thereof. The initial cliff angle has therefore also been represented as a Normally-distributed random variable, with mean and variance based on measurements of cliff angle within the CBU.

The cliff top position is calculated relative to the SCAPE prediction of cliff toe recession. From Figure 7 we see that the distance the cliff toe has to retreat until the first landslide is $h\left(\cot \alpha_{i}-\cot \alpha_{f}\right)$ and the distance lost between each subsequent landslide to the next is $h\left(\cot \alpha_{s}-\cot \alpha_{f}\right)$. For year $t+1$, the pre-landslide slope is taken from the post-landslide slope of year $t$. The cliff top recession process can be calculated from:

- SCAPE predictions of cliff toe recession,

- the cliff height (relative to the cliff base),

- the initial cliff angle $\alpha_{i} \sim N\left(\mu_{i}, \sigma_{i}\right)$, i.e. is a Normally-distributed random variable with mean $\mu_{i}$ and standard deviation $\sigma_{i}$, and,

- geomorphological assessments of the pre and post landslide angles $\alpha_{f} \sim N\left(\mu_{f}, \sigma_{f}\right), \alpha_{s} \sim N\left(\mu_{s}, \sigma_{s}\right)$.

Estimates of the parameters $\mu_{i}, \sigma_{i}, \mu_{f}, \sigma_{f}, \mu_{s}$ and $\sigma_{s}$ were obtained from limited geological data, site visits and analysis of aerial laser scanning and photogrametric images of the cliffs. The probability of a cliff landslide occurring is estimated by sampling from $\alpha_{i}$ and $\alpha_{f}$. The resultant cliff top position is then estimated by sampling from $\alpha_{s}$. Large numbers of samples of these sequences of angles are used to generate a time series of distributions of potential cliff top locations at each year through the $21^{\text {st }}$ Century. It is assumed that the only climatic influence on cliff recession is via shoreline (i.e. cliff base) recession, no changes to geotechnical factors (e.g. changing pore pressure from a different hydrological climate) are considered. The potential effects of hydrological changes on cliff stability were not considered.

\subsection{Reliability analysis of coastal and flood defences}

The three primary failure modes for the coastal defence structures found on the East Anglian coast are:

1. overflow: water level exceeds the flood defence crest level; 
2. overtopping: a combination of extreme waves and water levels results in waves running over the defence;

3. toe failure: low beach levels and/or excessive scour at the base of the defence lead to lowering or collapse of the flood defence.

Overflow of the flood defences along the Norfolk Broads is unlikely, even for an extreme water level (Table 1), due to the relatively high crest level of the beach and defence structures.

Overtopping discharges are estimated according to the roughness, permeability and slope of the flood defence structure (HR Wallingford, 1980; 1999). For example, the overtopping rate, $Q$, for an impermeable seawall is given by:

$Q=g H_{s} T_{m} a \exp \left[\frac{-b\left(z_{c}-z_{w}\right)}{T_{m} \sqrt{g H_{s}}}\right]$

where $H_{s}$ and $T_{m}$ are the significant wave height and the mean wave period at the toe of the structure, $z_{c}$ is the crest level, $z_{w}$ is the still water level, $g$ is the acceleration due to gravity and $a$ and $b$ are coefficients based on the slope and berm (HR Wallingford, 1999). Overtopping volumes in the study area are generally very small due to the height of the flood defence structures (with higher discharges being estimated for the lower seawalls south of Great Yarmouth). These overtopping discharges were then input directly into the flood inundation model described in Section 3.8.

The dominant mechanism for breach of a coastal defence is toe scour (CIRIA, 1986). This can lead to undermining and collapse of the coastal flood defence. This occurs when:

$z_{t}-z_{b}<0$

where $z_{t}$ is the level of the beach at the toe and $z_{b}$ is the critical beach level. The beach volume, taken from the SCAPE model is assumed to be evenly distributed over the shore platform. The post-storm beach profile is calculated using the approach of Vellinga (1983) for each value of $f(H, W)$ and the beach level, $z_{t}$, at the toe of the flood defence is subsequently extracted. Toe erosion is currently insufficiently understood to establish $z_{b}$ precisely (Reeve and Burgess, 1993, HR Wallingford, 2003). Therefore, a fragility function which describes the probability of toe failure conditional on beach level, was generated on the basis of generic coastal defence design evidence (c.f. Thomas and Hall, 1992, CIRIA and CUR 1991), data from site investigations (Environment Agency, 1996) and expert judgement. This provided estimates of the probability of one or more breaches, which was combined with information on breach width (Visser, 1998, Wahl, 1998, HR Wallingford, 2004) to calculate flood discharges into the floodplain due to flood defence breaching. 


\subsection{Coastal flood modelling}

Simulation of inundation over low-gradient floodplains with dike structures requires at least a twodimensional modelling approach with relatively high spatial resolution to represent the complex geometry of the floodplain. However, full two or three-dimensional modelling remains computationally prohibitive if multiple scenarios are to be modelled. To reduce the computational burden of the hydrodynamic calculations for this study a simple 2D raster-based inundation model called LISFLOOD-FP was selected. The model generates a spatial field of water levels from which the Digital Elevation Map (DEM) can be subtracted to give a field of flood depths. Bates and De Roo (2000) describe the model in detail which has been successfully demonstrated at a number of coastal sites and has been shown to perform as well as full two-dimensional codes at predicting maximum flood inundation extents (Horritt and Bates, 2001, Bates et al., 2005).

The model was set up using Lidar (Light Detecting and Ranging) surveys of the floodplain, with a spatial resolution of $2 \mathrm{~m}$, with a reported rms error of $0.1 \mathrm{~m}$. The model was implemented on a $250 \mathrm{~m}$ raster grid and validated against the 1938 flood event which provided a fitness measure of $91 \%$ giving significant confidence. Calibration of this model is described in more detail by Bates et al. (2005), and more detailed consideration to calibration of the LISFLOOD-FP model is described in Horritt and Bates (2001) and Hall et al. (2005).

The flood defence line was taken to be the open boundary of the model, with overtopping discharges and/or inflows through breaches simulated at appropriate points in the boundary. A dynamic tidal profile was used that corresponds in shape to the 1953 extreme event (Rossiter, 1954). The maximum flood depth for each model grid cell was extracted from a total of 20,000 runs of the hydrodynamic model and used to evaluate flood damages in the baseline risk calculation.

\subsection{Impacts analysis}

Two direct economic impacts are considered in the analysis:

(i) flood damage to property and agricultural production, and,

(ii) permanent erosion of cliff top properties and agricultural land

Flood damage was calculated using standard relationships between the depth of flooding and economic damage to different classes of property and agricultural land (Penning-Rowsell et al., 2005). Erosion damage was calculated using the risk-adjusted market value of cliff top property and agricultural land. The regional average market value (VOA, 2003, ODPM, 2003) of £208,824 has been supplemented with more local information from the UK Land Registry to estimate an average 
market value of $£ 150,000$ per residential postal address. Typical flood losses and erosion value of agricultural land at 2003 prices are summarised in Table 3.

Table 3 Losses by area for different classes of agricultural land at 2003 prices (erosion losses of agricultural land are reduced by $45 \%$ to account for government subsidies)

\subsection{Socio-economic futures}

The scenario framework shown in Figure 9 was used to produce four socio-economic scenarios for the coasts and floodplain fringing sub-cell 3b. This framework examines alternative directions in which social, economic and technological change may evolve over the coming decades in the UK, with a broadly individual versus collective action on the $x$ axis, and a broadly localised versus globalised world on the $y$ axis (DTI, 2002). The scenarios are discussed extensively in terms of future erosion and flood risks in Thorne et al. (2007), while more complete details of the scenario methods used in this study are in Nicholls et al (2005).

Figure 8 The four socio-economic scenarios (DTI, 2002) used to explore the impacts of socio-economic change on flood and erosion risk.

In contrast to earlier work that largely draws on expert judgement (e.g. Holman et al., 2005; Thorne et al., 2007), regional scenarios for changes to the built environment were developed and then spatially quantified across the case study domain using an algorithm-based methodology. The current baseline property distribution was kept fixed and then augmented with new properties based on the current regional housing policy forecasts (GOEE, 2005), and according to the four socioeconomic scenarios (DTI, 2002). The distribution of the new development is influenced by four attraction/repulsion factors for new build:

1. existing settlements,

2. the transport network,

3. the coastline, and,

4. the floodplain.

The number of properties is projected to increase under all four socio-economic scenarios. These attraction factors reflect the urbanisation policies and the levels of attraction that areas and infrastructures are likely to generate under the different socio-economic scenarios. For example, under the Local Stewardship scenario all the factors are negative indicating a trend of moving development into the countryside, which contrasts to the urbanisation trend of the World Markets 
scenario. Socio-economic change would be expected to alter the value of agricultural land as well as the value of property and its contents. Increases to property and contents values would be greatest under the World Markets and least (possibly even negative) under the Local Stewardship scenario, whilst increases to agricultural land values might only be expected under the national enterprise scenario (Evans et al., 2004).

Table 4 shows the numbers of both residential and non-residential properties located within the floodplain, the strength of each attractor for the four socio-economic scenarios, and the change in the number of non-residential properties relative to residential properties. The new properties were located according to a multi-criteria spatial weighting technique (Eastman et al., 1993). The attractors/repulsors were assigned the weights $w_{i}=[1 / 16 ; 1 / 8 ; 1 ; 8 ; 16]$ representing their relative importance under different socio-economic futures. The number of additional properties, $p_{j}$, added to flood damage cell $j$ (each cell has an area of $250 x 250 \mathrm{~m}$ ) is:

$P_{j}=\frac{P}{C} \sum_{i=1}^{n} w_{i}\left(1-\left[\frac{d_{i}-d_{\min }}{d_{\max }-d_{\min }}\right]\right)$

where $P$ is the total number of new properties to be added under a given socio-economic scenario, $C$ is the number of damage cells in the model domain (not including inland water body cells and others constrained from development), $n$ is the number of factors (note: $n>4$, as there are multiple settlements etc.), $w_{i}$ is the weight of factor $i, d_{i}$ the proximity of factor $i$ to cell $j$, and $d_{\min }$ and $d_{\max }$ correspond to the minimum and maximum values of the proximity of factor $i$ to cell $j$.

Table 4 The strength of the attractors for development and the total number of new properties by 2100 in the model domain (see Figure 1) and inside the 2003 floodplain under the four socio-economic scenarios. In 2003 the floodplain contained 16,766 residential properties (RP) and 3160 non-residential properties (NRP). 


\section{Results}

Results are presented in order of the modelling sequence (Figure 4): (1) coastal morphology, (2) flood analysis, and (3) risk analysis (validation of the wave propagation modelling is described by Stansby et al. (2006)). Presentation in this order helps to explain the important and rather complex results obtained from the risk analyses, which are an aggregation of the preceding steps with the socio-economic scenarios. The baseline data used for all the results is 2003.

\subsection{Coastal morphology}

The predictions of coastal erosion under the different scenarios of climate change and coastal management varied alongshore, and through time. Sea level rise has the most significant impact on erosion rates. However in some downdrift locations recession rates fell, because of a localised increase in beach volume caused by an increase in recession at the regional scale. This counterintuitive result illustrates the necessity of accounting for longshore interactions when exploring coastal recession at the scale of shoreline management (i.e. a sub-cell). A fuller description and interpretation of these results is given by Dickson et al. (2007). The effects of increased offshore wave heights were mitigated by energy dissipation across the shallow bathymetry of the North Sea which was assumed to be constant (as described previously). Consequently this had a small impact on erosion rates. Changes in offshore wave direction by $+/-10^{\circ}$ proved more important for erosion, with a clockwise rotation of the offshore wave rose generally increasing erosion rates, and an anticlockwise rotation reducing them.

The importance of coastal management on recession rates can be seen in Figure 9 (a), which shows the total recession predicted under scenarios 15, 24, \& 33. As can be seen in Table 2, these all assume high sea-level rise with unchanged waves, and the three most plausible management policies. No cliff recession occurs where seawalls have been maintained. Scenario 24 assumes the loss of structures from Bacton and Trimmingham, whilst under Scenario 33 the Mundesley and Overstrand structures are also allowed to fail. Structure loss results in high recession (e.g. at Overstrand under scenario 33). However, longshore sediment transport has an important mitigating effect. For example, the removal of structures at Bacton has a much smaller effect under scenario 33 than under scenario 24 due to beach sediments released by the updrift recession of Mundesley and Overstrand. Figure 9 (b) illustrates the high recession rates that initially follow structure failure as the coastline straightens, and the shore platform at the cliff toe returns to a more natural form.

Figure 9 (a) Total recession predicted along the cliffed frontage under scenarios 15, 24 \& 33 with 
71, 34 and 16\% coastal protection respectively, (b) recession distances under scenario 33 in 10 year timesteps. The letters H, B, M, T, O, C and S represent the locations of Happisburgh, Bacton, Mundesley, Trimingham, Overstrand and Sheringham respectively.

The release and southward transport of beach material also has an important influence on flood risk in the Norfolk Broads. Figure 10 illustrates the evolution of beach volumes under scenario 33 over the $21^{\text {st }}$ Century. It can be seen that there is a general decrease in beach volume with increasing distance from Winterton. Beach volumes are particularly large around the shore parallel reefs at Sea Palling. Diagonal bands of low/ high (dark/ light) beach volumes can be seen south of Mundesley, particularly before 2050, although also present elsewhere. These can be interpreted as the southward movement of sandwaves along the coast at approximately $0.8 \mathrm{~km} / \mathrm{year}$. In the model the sandwaves are promoted by the presence of engineering structures. This means that the spatiotemporal distribution of beach volume is more complex under scenarios with more engineering intervention. The relationship between the simulated and observed features has not been explored in depth and so this model behaviour should be interpreted with caution. However, the model waves are coupled to patterns of erosion in a manner observed by Pringle (1985) at the Holderness coast in the UK and there is anecdotal evidence of the existence of sandwaves of similar scale and speed south of Mundesley (Pers. Comm. Gary Watson, Environment Agency) which provides some confidence that these are not modelling artefacts. Figure 11 shows the frequency of occurrence of average beach volumes at Sea Palling throughout the $21^{\text {st }}$ Century under scenarios 15 , 24 and 33. These scenarios produce, respectively, increasingly stable beaches because they maintain decreasing levels of coast protection (i.e. there is less variance in beach level when a lower percentage of coastline is engineered).

Figure 10. Beach volumes $\left(\mathrm{m}^{3} / \mathrm{m}\right)$ to 2100 predicted under scenario 33 for the coastline north of Winterton. The letters on the vertical axes represent the locations of the settlements and the right hand bar provides the scale.

Figure 11 Histogram of average annual beach volumes from 2020-2100 for scenarios 15, 24 and 33 with 71,34 and $16 \%$ coastal protection respectively. There is increased variability in beach volume along the coast when more engineering structures are present. 


\subsection{Flood analysis}

For all scenarios, the flood defence structures were assumed to be maintained to their current levels to explore the relative impacts of broad scale erosion management strategies on mitigating this flood risk.

Figure 12 illustrates the changing annual probability of flooding in the Norfolk Broads. The plot shows considerable interannual, and longer, variability but the general future trend suggests an increasing probability of flooding - particularly under the higher sea level rise scenario. Figure 13 illustrates how fluctuations in beach volume, and subsequently beach toe level, are amplified in the calculation of breach probabilities for the flood defences, which in this area are critically dependent on the beach level in front of them. This mechanism can be understood by consideration of the beach in Figure 2, where it can be observed that in its present state the beach, seawall and dune together provide a reasonable level of protection, whilst beach lowering by several metres would greatly increase the probability of seawall overturning and rapid erosion of the dune. Figure 14 provides a broad scale overview showing the most probable cliff top erosion distance and the inundation probability in 2003 and 2100. The actual cliff top erosion distance may be substantially more or less than this depending on the cliff properties (Section 3.6)

Figure 12 Time series of annual flood probability (for a water depth greater than $0 \mathrm{~m}$ ) for low, med and high sea-level rise (Scenarios 10, 14 and 15) at E:645075, N:322775 just inland of the midpoint between Sea Palling and Winterton Ness

Figure 13 The influence of beach morphology on defence failure probability for a flood defence in front of the Norfolk broads for Scenario 19

Figure 14 Map of most probable (i.e. maxima of the p.d.f. $f_{c}\left(x \mid x_{s}, y, t\right)$ )described in Equation 1) cliff top erosion extent (metres) and the annual probability of flooding (to a depth of greater than $0 \mathrm{~m}$ ) for (a) in 2003 and (b) in 2100 for Scenario 15 with high sea-level rise and 71\% of the coast protected. Darker shades imply greater probability of recession and flooding.

\subsection{Risk analysis}

The results of the risk analysis are presented in 2003 prices. Figure 15 illustrates separately the erosion risk, $r_{c}$, and the flood risk, $r_{f}$. The flood risk at the site is at least an order of magnitude greater than the erosion risk in the base year and potentially increases at a greater rate. The flood 
risks grow exponentially during the latter half of the $21^{\text {st }}$ Century whilst the erosion risk is predicted to remain relatively constant through the $21^{\text {st }}$ Century, assuming the baseline socio-economic scenario. The difference between the two risks is further illustrated in Figure 16, which shows how the erosion risk is concentrated in a narrow band near the coast, whereas the flood risk zone extends far in land. The differences between the risk functions associated with the two hazards arise because:

- properties can be flooded on multiple occasions, whereas they can only be eroded from a cliff top once. Taking this to its most extreme: if an entire coastal settlement is eroded over the course of the $21^{\text {st }}$ Century the risk will decrease to near zero once the settlement has disappeared and all that remains is the agricultural hinterland.

- there are fewer properties at risk of erosion over the $21^{\text {st }}$ Century than at risk of flooding which reflects that the flood risk zone is larger and more populous than the erosion risk zone (Table 4), and,

- for a given return period, sea-level rise increases the area at risk of flooding, and depth of inundation over the entire floodplain, whilst its influence on erosion is more complex as accelerated cliff recession generates additional sediment which can reduce recession rates elsewhere along the coastline (Dickson et al., 2007). In both cases, the relationship between sea level rise and risk is not linear.

Figure 15 also illustrates the trade-off associated with different cliff management options. Whilst cliff protection reduces erosion risks (at a cost) it also reduces sediment supply to the flood-prone down-drift coast, leading to the potential for rapidly increasing flood risks over the $21^{\text {st }}$ century (assuming no improvement in flood defence infrastructure). The erosion risk for the $100 \%$ protection management scenario is never zero, because there is always a finite probability of a failure: despite the presence of cliff protection, landslides can still occur (c.f. Frew and Guest, 1997) and so there is still an erosion risk. However, over the $21^{\text {st }}$ century the erosion risk associated with this scenario decreases due to the slope of the cliff tending towards an increasingly stable angle. Removal of cliff protection results in increasingly severe economic losses on the cliffed coastline according to the amount of protection lost. On the other hand, while the removal of cliff protection will result in significant economic losses on the cliffed coastline, the gains are usually of an order of magnitude greater, in terms of risk reduction, on the flood-prone coast - as shown in Figure 15(b) by the timeseries plot of Scenario 42. Of particular note is that whilst the flood risk does increase from around $£ 4 \mathrm{~m}$ to $£ 11 \mathrm{~m}$, the majority (60\%) of this increase comes from the floodplain South of Winterton Ness that do not benefit from the additional sediment influx from the eroding cliffs (i.e. 
where the main driver of changes to flood risk is from sea level rise). The implications for coastal management of this insight are discussed further below.

Figure 15 Comparison of the evolution of (a) erosion and (b) flood risks over the $21^{\text {st }}$ Century under a high climate change scenario and assuming no change in socio-economic vulnerability: Scenarios 6, 15, 24, 33, 42 (Note: (a) and (b) are plotted to different scales) represent decreasing levels of cliff protection.

Figure 16 Map of flood and erosion risks, expressed in terms of expected annual damages (a) at present and (b) in 2100 for Scenario 15 with constant socio-economic conditions. The cliff erosion risk has been scaled to the area of a flood cell $(250 \mathrm{~m} \times 250 \mathrm{~m})$. Darker shades imply a greater risk.

Figure 17 illustrates the effect of different sea-level rise scenarios on the projections of risk, assuming the baseline socio-economic scenario and $71 \%$ coastal protection. The results reflect the predicted changes in the probability of flooding shown in Figure 12. Current observed rates of sealevel rise are reflected in more or less steady risk levels over the $21^{\text {st }}$ Century. However, a tripling of the rate of sea-level rise from current rates to $4.5 \mathrm{~mm} /$ year over the $21^{\text {st }}$ Century results in only an approximate doubling of the flood risk. The reduction is because rising sea levels will result in increasing release of sediments from the up-drift cliffed coast (see Figure 9). However, this feedback is insufficient to compensate for the effect of larger changes in climate: a $1.2 \mathrm{~m}$ sea-level rise over the $21^{\text {st }}$ Century results in greatly increased levels of flood risk. Somewhere in between the medium and high scenarios a major threshold in coastal behaviour occurs, which could be thought of as constituting 'dangerous' climate change (according to the definition given by the UN (1994)). The most marked differences become noticeable over the second half of the $21^{\text {st }}$ Century; before that time the difference between scenarios does not exceed the range of variability in the output from the coastal models.

Figure 17 The effect of sea-level rise on the evolution of flood risk over the $21^{\text {st }}$ Century for Scenarios 10, 14 and 15 (low, medium and high respectively) assuming no socio-economic change

The effects of increases in offshore wave heights had little impact on erosion rates, and consequently flood risk. Whilst changes in offshore wave direction by $+/-10^{\circ}$ proved more 
significant in terms of erosion, the consequent changes in available sediments were not sufficient to result in a noticeable impact on the flood risk.

All 45 scenarios representing different combinations of climate change, coastal management and socio-economic scenarios are summarised in Figure 18 in terms of net present risks (i.e. total expected annual damages discounted to 2003 prices at a discount rate of 3.5\% for the first 30 years, 3\% for the subsequent 45 years and 2.5\% thereafter as recommended by HM Treasury (2003)). Figure 18 indicates that for high sea level rise scenarios, the lowest net present risk is to remove all cliff protection. However, for low and medium sea level rise scenarios, the increase in cliff erosion risk would not be offset by gains in flood risk reduction. In these cases the two interim management solutions that remove a portion of the existing protection would give the lowest net present economic risks. However, the use of a fixed discount rate over such an extended timescale is questionable, as is the use of a constant discount rate for different socio-economic scenarios which will have quite different associated rates of economic growth and attitudes towards the value of the future (Thorne et al., 2007). This is perhaps most evident when comparing low and medium sea level rise risks which, when discounted, are only marginally different as the two risk profiles only diverge later in the $21^{\text {st }}$ century. Our aim in presenting discounted risks is not to provide a basis for cost-benefit analysis, but merely as a convenient means of summarising a large number of results integrated over time. Were a higher discount rate to be used the expected damages from flooding towards the end of the $21^{\text {st }}$ Century, when it is greatest, would be weighted less, thereby reducing the net present benefits of removing cliff protection, and vice versa.

As might be intuitively expected, socio-economic growth in the region acts to increase flood risk as analysed in terms of changes to the built environment. In all cases the damages are increased, with average increases in direct damages (at 2003 property and agricultural prices) of $6 \%, 9 \%, 16 \%$ and 19\% under the Local Stewardship, Global Sustainability, National Enterprise and World Markets futures, respectively. Thus, the effects of this growth on flood risk are, given the assumptions made in this study, of a similar order of magnitude when compared to a medium sea-level rise scenario and relatively insignificant when compared to the highest potential sea-level rise scenarios. However, these damages assume a constant depth-damage relationship through time, while recent experience has observed these functions to be dynamic due to the rising value of goods in properties (Penning-Rowsell et al., 2003). However, a key insight from this work is that doubling of the number of properties (as occurs in the World Markets scenarios) does not imply a doubling of flood risk. This is because the location of development is crucial in determining the change in risk: development in floodplain locations with lower inundation probability contributes less towards 
flood risk when compared to development in areas of the floodplain that experience more frequent inundation. Likewise, development on higher ground in the floodplain will lead to lower damages for a given flood event because the depth of flooding is likely to be less. The sensitivity of risk estimates to these and other socio-economic changes should be explored in future studies.

Figure 18 Net present risks for each combination of management and socio-economic scenario clustered according to climate scenarios (see Table 2 for details)

\section{Implications for coastal management}

The results from this study have quantified the connectivity between the various geomorphological features that comprise the natural coastal system and shown, quantitatively for the first time, that the vulnerabilities of the different parts of a coastal sub-cell are not independent. Clearly it is inappropriate to consider erosion and flood hazards in isolation. Rather, analysis of climate impacts and long-term coastal management must be implemented at a broader scale that accounts for this morphological interdependence. Currently, this is generally not the case. Coastal erosion and flooding are typically assessed independently and the governance structures do not always match the scale at which management is required. In this paper we have presented a method for integrated analysis of flood and erosion risks over extended timescales that enables management scenarios to be appraised under a range of plausible future climatic and socio-economic conditions using risk as a common currency to support decision-making.

Whilst the research presented here is considered to be a substantial contribution towards providing decision-makers with some of the necessary information to support integrated coastal zone management, key challenges remain, including the reduction of the vulnerability of coastal populations to climate impacts and the implementation of appropriate governance processes for the management of a transition towards a more sustainable configuration. Within the UK there are, however, moves to develop a more holistic approach to flood and erosion management that is risk based (DEFRA, 2005), and recently there have been a range of strategies, consultations and planning documents produced that impact on the management of the coast (Milligan et al. 2006). Of particular importance are Shoreline Management Plans which have defined sub-cells and cells, providing a framework for the methods described here (MAFF et al., 1995; DEFRA, 2001; 2006). Other important initiatives include Making Space for Water (DEFRA, 2004), planning guidance through Planning Policy Statement 25 (DCLG, 2006) and Local Development Frameworks (ODPM, 2004) and a number of coastal and maritime strategies (English Nature, 2005, Environment Agency, 
2005, National Trust, 2005). Integrated coastal zone management is also being developed within Europe (European Commission, 2000) and more widely (c.f. RIKZ et al., 2005). Whilst it is clear that the various authorities involved in the management of the coastline are increasingly working together (Wright, 2004) there are a range of issues, both in the UK (Milligan et al., 2006) and elsewhere (Moser, 2005), that remain to be addressed around the extent to which integrated coastal zone management should be developed, funding and institutional arrangements, planning issues and public perceptions and expectations.

The progressive transformation of policy in the UK is proving controversial due to commonplace expectation amongst the general public that a 'hold the line' policy will be maintained. As identified in the review of management options, this is becoming increasingly challenged by policy makers and shoreline planners. Nevertheless, strengthening community and stakeholder involvement is a key principle underlying the new planning system in England and Wales (ODPM, 2004). Inclusion remains a difficult task because of the dynamic complexity of coastal systems and the difficulty of communicating uncertainty to a wide range of stakeholders (Brown et al., 2006). These difficulties become especially apparent when one considers the need to 'involve stakeholders at all levels of risk management' and achieve a better balance 'between the three pillars of sustainable development (economic, social and environmental) in ... risk management activities' (DEFRA, 2005). However, as demonstrated in this paper, economic arguments do not necessarily conflict with the environmental reasons for allowing some of the coastline to return to a more natural configuration. However, whilst this work goes some way to supporting decision-makers, this type of analysis is incomplete in itself as environmental and equity issues must also be considered - we do not, for example, underestimate the serious social implications of allowing coastal settlements to be lost.

With the increase in emphasis on improving participation and consultation, there is a need to consider new techniques that can aid the communication of coastal information to the public (Jude et al., 2006). GIS visualisation techniques provide one such method to motivate and engage stakeholders (Jude et al. 2005; 2006; Nicholson-Cole 2005). Outputs from the erosion model presented here have been linked with a GIS to develop a visualisation of the evolving coastal environment (Figure 19); the credibility of the resulting virtual landscapes are enhanced by their derivation from scientific data provided by the simulation model (Brown et al., 2006).

Figure 19 Virtual reality visualisation of coasts (each line represents a 10 year central estimate of the cliff toe position) 
The major implications for coastal management are, therefore that:

1. Management of the coastline and the governance structures on which that management depends need to reflect the connectivity, and consequential tradeoffs in management policy, between the various geomorphological features that comprise the natural coastal system. This paper demonstrates that the tools are now available to conduct the analyses required to support such management, at least for open-coast settings. However, the principles shown here could be applied in other environments such as estuaries and deltas (which have been identified as very vulnerable to climate change by Nicholls et al. (2007b)) using appropriate models for the analysis.

2. The economic analysis strengthens the argument for allowing some of the coastline to return to a more natural configuration and for negotiating compensation to landowners and householders to facilitate a change back to a more natural and dynamic shoreline. Such decisions should be based on multiple criteria encompassing economic, environmental and social dimensions.

3. Given the uncertainties in the future sea level rise, and the extent to which this influences the effectiveness of different management strategies, an adaptive strategy that is continuously reviewed in the light of new information is most appropriate.

4. Further work is needed to better understand the socio-economic issues associated with coastal risk management. However, visualisation of the results from the simulation models provide a potentially powerful tool for motivating and engaging policy makers and stakeholders.

\section{Conclusions}

A systematic appraisal of the effects of climate and socio-economic change and coastal management policy on risks associated with coastal erosion and flood risk has been described. This has been achieved by coupled modelling of water levels, waves, coastal morphology and risk analysis over the whole of a reasonably self-contained coastal system (UK sub-cell $3 \mathrm{~b}$ ). The results of coastal management and climate change scenarios for two natural hazards have, for the first time, been presented quantitatively in terms of changes in expected annual damage thereby enabling direct economic evaluation of local effects of modifying coastal cliff erosion compared with potential broader-scale effects on flood risk. The analysis indicates that the main drivers for flood risk over the $21^{\text {st }}$ Century in northern East Anglia are a consequence of a combination of:

- $\quad$ rising sea levels; 
- local and broad-scale natural and anthropogenically driven morphological change, that may lower or raise beach levels;

- changes in exposure to flooding and erosion due to socio-economic changes.

Increases in wave height are found to be less significant than these factors owing to attenuation across the nearshore and are only felt on the coast if accompanied by high sea-level rise. Possible changes in wave direction have a more noticeable influence on coastal morphology, but this does not translate into significant changes in economic risk. Although the risk profiles will be different for other locations, the key drivers are likely to be the same in similar settings around the world's coasts.

A rapidly increasing sensitivity to sea level is predicted for rates of mean sea-level rise greater than about $4.5 \mathrm{~mm} /$ year. This corresponds to an increase in global average surface air temperature of $3.3^{\circ} \mathrm{C}$ and total atmospheric $\mathrm{CO}_{2}$ of $715 \mathrm{ppm}$, whilst the high sea-level rise scenario corresponds to 970ppm and $4.5^{\circ} \mathrm{C}$ (Church et al., 2001, Hulme et al., 2002) although there is uncertainty in this relationship about the mean values presented here. Risk functions will differ between regions (e.g., Nicholls, 2004), but the possibility of such a high degree of non-linearity for potential impacts will have significant implications for policy makers concerned with global emissions mitigation. Further investigation of these thresholds for the scale of sub-cells up to regions and even globally would be useful.

The results demonstrate that over the $21^{\text {st }}$ Century, significant benefits in terms of mitigating flood risk can be obtained by allowing previously defended cliffs to erode naturally. These benefits are greatest under high sea level rise scenarios. However, the economic and social implications for cliff-top communities of such a policy are significant. The changes in risk are predicted to be quite steady over the first half of the $21^{\text {st }}$ Century, allowing time for planned adaptation. However, given the slow turnover of housing and infrastructure, plans for managed retreat from parts of the coast need to be implemented now if excessive adaptation costs are not to be incurred in the latter half of the $21^{\text {st }}$ Century.

Because of the uncertainty in future sea level rise, and the extent to which this rise influences the effectiveness of the removal of cliff protection on flood risk reduction, an adaptive strategy that can be modified according to the actual sea level rise is appropriate. Management of the coastline and the governance structures on which that management depends need to reflect the connectivity between the various geomorphological features that comprise the natural coastal system. This paper shows that the tools are now available to conduct the analyses required to support such management. 
Given the benefits in terms of risk reduction that this study has demonstrated, a cogent case can be made for compensation of cliff top communities who have to make way to allow coastal erosion to proceed.

The uncertainties in generating predictions of coastal erosion and flood risk over extended timescales are considerable. We have grounds for some confidence in the results because of the validation and track record of the TOMAWAC and Lisflood models and critically (for simulation of long term change) the validation and stability of the morphological model (Dickson et al., 2007). However, major uncertainties, associated with climate change and socio-economic change have merely been dealt with in terms of scenarios. Extension to include probabilistic climate scenarios and dynamical downscaling of waves and surges from regional climate models is planned. Whilst we have sought to give a reasonable coverage of combinations of climate change, socio-economic change and coastal management, not all possible options have been tested and that other combinations of emissions, coastal management and socio-economic scenarios could be realised.

The analysis has integrated knowledge on complex natural, engineered and social systems: regional climate predictions have driven hydrodynamic and morphological models and captured the dynamic effects of climate change and its interaction with the natural, engineered and social systems. Such a broad analysis can never be complete, nor can we expect to deal with individual process within this interacting system in utmost detail. However, the rationale is that that by representing the dominant interactions that determine the long term behaviour of the system the response to changes, be they due to climatic change or coastal management, can be simulated with some degree of confidence. By quantifying the impacts of these changes in terms of the common currency of risk, better information is available to decision-makers and the management policies concerning different hazards and involving multiple stakeholders can be more effectively communicated.

\section{Acknowledgements}

This research was funded by the Tyndall Centre for Climate Change Research through the ongoing coastal programme (http://www.tyndall.ac.uk/research/programme5/). The Environment Agency for England and Wales provided LiDAR data, surveys of flood protection structures and the National Property Database. Tide data were supplied by the British Oceanographic Data Centre as a part of the function of the National Tidal and Sea Level Facility. The wave time series was supplied by $H R$ Wallingford Ltd., who also determined the storm conditions under which material moved to and from the offshore. The British Geological Survey provided geomorphic information for model 
calibration. Information on the history of construction along the cliffed coastline was provided by Peter Lawton (St. La Haye Consulting Engineers) and North Norfolk District Council. Previous development of SCAPE has been funded through the UK Engineering and Physical Sciences Research Council, as well as the North Norfolk District Council and Halcrow. Previous development of the flood risk analysis methodology has been funded through the joint Research and Development Programme of the Department for Environment, Food and Rural Affairs and Environment Agency of England and Wales as the RASP (Risk Assessment for Strategic Planning) project. Mark Dickson is currently supported by a fellowship provided by the Foundation for Research, Science and Technology (New Zealand).

\section{References}

Bates, P.D. and De Roo, A.P.J.: 2000, ‘A simple raster-based model for floodplain inundation’, $J$. Hydrology, 236:54-77.

Bates, P.D., Dawson, R.J., Hall, J.W., Horritt, M.S., Nicholls, R.J., Wicks, J. and Hassan, M.A.A.M.: 2005, 'Simplified two-dimensional modelling of coastal flooding for risk assessment and planning', Coastal Engineering, 52(9):793-810.

Bouws, E. Jannink, D. and Komen, G. J.: 1996, 'The increasing wave height in the North Atlantic Ocean’, Bull. Am. Meteorol. Soc., 77(10):2275-2277.

Brown, I., Jude, S., Koukoulas, S., Nicholls, R., Dickson, M. And Walkden, M.: 2006, 'Dynamic simulation and visualisation of coastal erosion', Computers, Environment and Urban Systems, 30:840-860.

Bruun, P.: 1962, ‘Sea-Level Rise as a Cause of Shore Erosion', Proc. ASCE: J. Waterways and Harbors Division, 88:117-130.

Burgess, K., Jay, H. and Nicholls, R. J., Green, C. and Penning-Rowsell, E. C.: 2007, 'Assessment of future coastal erosion risk', in C. Thorne, E. Evans, E. C. Penning-Rowsell (eds.), Future flooding and coastal erosion risks, Thomas Telford, London.

CERC: 1984, Shore Protection Manual, US Army Engineer Waterways Experiment Station Coastal Engineering Research Centre, Vicksburg, MS.

Chang, S.-C. and Evans, G.: 1992, 'Source of sediment and sediment transport on the east coast of England: Significant or coincidental phenomena?’ Marine Geology. 107:283-288.

Church, J.A., Gregory, J.M., Huybrechts, P., Kuhn, M., Lambeck, K., Nhuan, M.T., Qin, D. and Woodworth, P.L.: 2001, Climate Change 2001: The Scientific Basis. Intergovernmental Panel on Climate Change Third Assessment Report, Cambridge University Press. 
CIRIA 1986: Performance of Sea Walls: Technical Note 126, CIRIA, London.

CIRIA and CUR, 1991: Manual on the use of rock in coastal and shoreline engineering, CIRIA Special Publication 83/CUR Report 154, CIRIA, London.

Clayton, K.M.: 1989, Sediment input from the Norfolk Cliffs, Eastern England - A Century of coast protection and its effect. Journal of Coastal Research. 5, 433-442.

Cooper, N., Bray, M., Carter, D. and Barber, P.: 2002, 'Shoreline Management Plans: a national review and engineering perspective', Proc. of the Institution of Civil Engineers: Water and Maritime Engineering, 154(3), 221-228.

Dawson, R.J. and Hall, J.W.: 2006, 'Adaptive importance sampling for risk analysis of complex infrastructure systems', Proc. R. Soc. A, 462(2075), 3343-3362.

DCLG 2006, Planning Policy Statement 25: Development and Flood Risk. TSO, London.

DEFRA: 2001, Shoreline management plans: A guide for coastal defence authorities. June 2001. DEFRA: 2004, Making space for water: Developing a new Government Strategy for flood and coastal erosion risk management in England. A consultation exercise. July 2004 (http://www.defra.gov.uk/environ/fcd/policy/strategy.htm).

DEFRA: 2005. Taking forward a new Government strategy for flood and coastal erosion risk management in England. First Government response to the autumn 2004 Making space for water consultation exercise (http://www.defra.gov.uk/environ/fcd/policy/strategy/1stres.pdf)

DEFRA: 2006, Shoreline Management Plan guidance - Volume 1: Aims and requirements Volume 2 :Procedures March 2006,

(http://www.defra.gov.uk/environ/fcd/pubs/smp/revisedsmpguidancefinal.pdf)

DTI: 2002, Foresight Futures 2002: Revised Scenarios and Guidance, UK Department of Trade and Industry, London.

Dixon, M.J. and Tawn, J.A.: 1997, Estimates of extreme sea conditions. Proudman Oceanographic Laboratory. Report 112, p. 217.

Dickson, M. E., Walkden, M. J. A. and Hall, J. W.: 2007, 'Systemic impacts of climate change on an eroding coastal region over the twenty-first century', Climatic Change, 84(2):141-166.

Eastman, J.R., Kyem, P.A.K, Toledano, J., \& Jin, W.: 1993, GIS and decision making. Explorations in Geographic Information Systems Technology, Vol. 4. Geneva: United Nations Institute for Training and Research (UNITAR).

English Nature, DEFRA, Environment Agency, Natural Environment Research Council and LIFEEU: 2003, Winterton Dunes: Coastal Habitat Management Plan, April 2003. 
Environment Agency: 1996, East Anglian Sea Defence Survey, Environment Agency, Peterborough.

Environment Agency: 2005, Cleaner coasts, healthier seas. Working for a better marine environment: Our strategy for 2005-2011

(http://www.environment-agency.gov.uk/subjects/conservation/208776/1209976)

European Commission: 2000, Communication from the commission to the council and the European parliament on integrated coastal zone management: A strategy for Europe, Commission of the European Communities, $\operatorname{COM}(2000,547$ final, Brussels.

Eurosion: 2004, Living with coastal erosion in Europe: sediment and space for sustainability: Major findings and policy recommendations of the EUROSION project. European Commission, Directorate General Environment, Service contract B4-3301/2001/329175/MAR/B3.

Frew, P. and Guest, S.: 1997, 'Overstrand coast protection scheme', in Proc. MAFF Conference of River and Coastal Engineers, MAFF, London.

Gregory, J.M., Church, J.A., Boer, G.J., Dixon, K.W., Flato, G.M., Jackett, D.R., Lowe, J.A., O'Farrell, S.P., Roeckner, E., Russell, G.L., Stouffer, R.J. and Winton, M.: 2001, 'Comparison of results from several AOGCMs for global and regional sea-level change 1900-2100', Climate Dynamics. 18, 225-240.

Grieve, H.: 1959, The Great Tide: The story of the 1953 flood disaster in Essex. Essex County Council, 833pp.

GOEE: 2005, Regional housing strategy for the East of England, Government Office for the East of England.

Halcrow: 1999, Gorleston to Lowestoft Coastal Strategy Study, Halcrow Group Ltd.

Halcrow: 2002, Futurecoast. DEFRA.

Halcrow: 2007, Happisburgh to Winterton Sea Defences Stage 3b Project Appraisal Report: Appendix B, Halcrow.

Halcrow, English Nature, Environment Agency, North Norfolk District Council, Great Yarmouth Borough Council, Waveney District Council and Great Yarmouth Port Authority: 2006, Kelling to Lowestoft Ness Shoreline Management Plan Review, Anglian Coastal Authorities Group.

Hall, J. W., Lee, E. M. and Meadowcroft, I. C.: 2000, 'Risk-based benefit assessment of coastal cliff protection', Proc. Inst. Civil Engineers: Water and Maritime Engineering, 142(Sept), 127-139.

Hall, J.W., Dawson, R.J., Sayers, P.B., Rosu, C., Chatterton, J.B. \& Deakin, R.: 2003, ‘A methodology for national-scale flood risk assessment', Water and Maritime Engineering, ICE, 156(3), 235-247. 
Hall, J.W., Tarantola, S., Bates, P.D. and Horritt M.S. Distributed sensitivity analysis of flood inundation model calibration, J. Hydraulic Engineering, ASCE, 131(2) (2005) 117-126. Hall, J. W., Sayers, P. B., Walkden, M. J. A. and Panzeri, M.: 2006, 'Impacts of climate change on the coast of England and Wales: 2030-2100’, Phil. Trans. R. Soc. A: Special Issue on the Science of Sea Level Rise, 364(1861), 1027-1049.

Harland, M. G. and Harland H. J.: 1980, The flooding of Eastern England, Minimax Books, Peterborough, UK.

Hawkes, P.J., Gouldby, B.P, Tawn, J.A. and Owen, M.W.: 2002, 'The joint probability of waves and water levels in coastal engineering', Journal of Hydraulic Research, 40(3), 241-251.

Holman I.P., Loveland P.J., Nicholls R. J., Shackley S., Berry P.M., Rounsevell M.D.A., Audsley E., Harrison P.A., and Wood R.: 2002, REGIS -Regional Climate Change Impact and Response Studies in East Anglia and North West England, UKCIP and DEFRA, Oxford and London. Holman, I.P., Rounsevell, M.D.A., Shackley, S., Harrison, P.A., Nicholls, R.J., Berry, P.M., \& Audsley, E.: 2005, 'A regional, multi-sectoral and integrated assessment of the impacts of climate and socio-economic change in the UK: I Methodology’, Climatic Change, 71(1-2), 9-41.

Horritt, M.S. and Bates, P.D.: 2001, 'Predicting floodplain inundation: raster-based modelling versus the finite element approach', Hydrological Processes, 15: 825-842.

HM Treasury: 2001, Management of risk: A strategic overview, London: HM Stationery Office. HM Treasury: 2003, The Green Book: Appraisal and Evaluation in Central Government, London: HM Stationery Office.

HR Wallingford: 1980, Design of seawalls for wave overtopping, Report EX924, HR Wallingford. HR Wallingford: 1999, Overtopping of Seawalls: Design and Assessment Manual. R\&D Technical Report W178.

HR Wallingford: 2002, Overstrand to Mundesley Strategy Study: Hydrodynamics'. HR Wallingford Ltd. Report.

HR Wallingford: 2003, Beach lowering in front of coastal structures, DEFRA/EA R\&D Scoping Study Report FD1916/TR, DEFRA, London.

HR Wallingford: 2004, Investigation of extreme flood processes \& uncertainty, (IMPACT, EC Research Project no. EVG1-CT2001-00037.: www.impact-project.net).

Hulme, M., Jenkins, G.J., Lu, X., Turnpenny, J.R., Mitchell, T.D., Jones, R.G., Lowe, J., Murphy, J.M., Hassell, D., Boorman, P., McDonald, R. \& Hill, S.: 2002, Climate Change Scenarios for the 
United Kingdom: The UKCIP02 Scientific Report. Tyndall Centre for Climate Change Research, School of Environmental Sciences, University of East Anglia, Norwich, UK. 120pp.

Jude, S., Brown, I., Koukoulas, S., Dickson, M., Walkden, M., Jones, A. \& Watkinson, A.: 2005, 'Exploring Future Coastlines: Initial Steps Towards the Development of an Integrated Coastal Simulation and Visualisation System’, in E. Buhmann, P. Paar, I. J. Bishop and E. Lange (eds.) Trends in Real-Time Landscape Visualization and Participation, Herbert Wichmann Verlag, Heidelberg, pp. 69-76.

Jude, S., Jones, A.P., Andrews, J.E., and Bateman, I.J.: 2006, ‘Visualisation for participatory coastal zone management; a case study of the Norfolk coast', England. Journal of Coastal Research, 22: $1527-1538$.

Kelman, I.: 2003, 1953 Storm Surge Deaths: U.K. Version 4, 10 November 2003, Downloaded from http://www.ilankelman.org/disasterdeaths/1953DeathsUK.doc

Komar, P.D.: 1988, Beach Processes and Sedimentation, Second Edition, New Jersey, Prentice Hall. Kuang, C.P. and Stansby, P.S.: 2004, 'Modelling directional random wave propagation inshore', Proc. Inst. of Civil Engineers: Water Maritime and Energy. 157, 123-131.

Kushnir, Y., Cardone, V. J., Greenwood, J. G. and Cane, M. A.: 1997, 'The recent increase in North Atlantic wave heights', J. Climate, 10(8), 2107-2113.

Leafe, R., Pethick, J. and Townend, I.: 1998, 'Realizing the benefits of shoreline management', Geographical Journal, 164(3), 282-290.

Lee E. M., Clark A. R. and Guest S.: 1998, An assessment of coastal landslide risk, Scarborough, UK. Proceedings of the 8th International Association of Engineering Geology and the Environment Congress, Vancouver, 1998, pp1787-1794.

Ministry for Agriculture, Fisheries and Food, Welsh Office, Association of District Councils, English Nature and National Rivers Authority 1995, Shoreline Management Plans: a guide for coastal defence authorities, MAFF, London.

Miller, L. and Douglas, B.C.: 2004, 'Mass and volume contributions to twentieth-Century global sea level rise', Nature, 428, 406-409.

Milligan, J., O’Riordan, T. and Watkinson, A.: 2006, Designing coastlines fit for the future. English Nature research Reports No 702, Peterborough, UK.

Mosby, J. E. G.: 1938, 'The Horsey Flood, 1938: An example of storm effect on a low coast', Geographic Journal, 93(5), 413-418. 
Moser, S. C.: 2005, 'Impacts assessments and policy responses to sea-level rise in three U.S. states: An exploration of human dimension uncertainties', Global Env. Change, 15: 353-369.

National Research Council: 1992, Risk assessment in the Federal Government: improving the process, National Academy Press.

Nairn, R.B. and Southgate, H.N.: 1993, 'Deterministic profile modelling of nearshore processes. Part 2. sediment transport and beach profile development', Coastal Engineering, 19: 57-96.

National Trust: 2005, Shifting shores: living with coastal change, http://www.nationaltrust.org.uk/main/w-shifting_shores.pdf)

Nicholls, R.J.: 1995, 'Coastal Megacities and Climate Change’, Geojournal, 37(3), 369-379.

Nicholls, R.J.: 2004, 'Coastal flooding and wetland loss in the 21st Century: Changes under the SRES climate and socio-economic scenarios’, Global Environmental Change, 14: 69-86.

Nicholls, R.J., Mokrech, M., Richards, J., Bates, P., Dawson, R., Hall, J., Walkden, M., Dickson, M., Jordan, A. and Milligan, J.: 2005, Assessing coastal flood risk at specific sites and regional scales: Regional assessment of coastal flood risk, Tyndall Centre Technical Report No. 45. October 2005 http://www.tyndall.ac.uk/research/theme4/final_reports/t2_46.pdf

Nicholls, R.J., Tol, R.S.J. and Hall J.W.: 2007a, ‘Assessing Impacts and Responses to Global-Mean Sea-Level Rise’, in Schlesinger (ed) Climate Impact Assessment, Cambridge University Press, in press.

Nicholls, R.J., Wong, P. P, Burkett, V. R., Codignotto, J. O., Hay, J. E., McLean, R. F., Ragoonaden, S. and Woodroffe, C. D.: 2007b, 'Coastal systems and low-lying areas. Climate Change 2007: Impacts, Adaptation and Vulnerability’ in Parry, M.L., Canziani, O.F., Palutikof, J.P., van der Linden, P.J. and Hanson, C.E. (eds.), Contribution of Working Group II to the Fourth Assessment Report of the Intergovernmental Panel on Climate Change, Cambridge University Press, Cambridge, UK, 315-356.

Nicholson-Cole, S.: 2005, 'Representing climate change futures: a critique on the uses of images for visual communication’, Computers, Environment and Urban Systems, 29:255-273.

NNDC: 2006, North Norfolk Local Plan: B35 Chapter 7 - Environmental Safety, North Norfolk District Council, updated March 31st 2006 (www.north-norfolk.gov.uk/planning/).

Nordhaus, W.: 2006, 'Geography and macroeconomics: New data and new findings', Proc. Nat. Acad. Sci., 103: 3510-3517.

ODPM: 2003, Housing market: Simple average house prices, Office of the Deputy Prime Minister, London. 
ODPM: 2004. Planning Policy Statement 12: Local Development Frameworks, Office of the Deputy Prime Minister, London.

Parry, M.L.: 2004, 'An assessment of the global effects of climate change under SRES emissions and socio-economic scenarios’, Global Environmental Change, 14: 1-99.

Pelnard-Considere, R.: 1956, Essai de theorie de l'evolution des forms de ravage en plage de sable et de galets. 4th Journees de l'Hydraulique, Les Energies de la Mer. Question III, 792-808.

Penning-Rowsell, E.C., Johnson, C., Tunstall, S.M., Tapsell, S.M., Morris, J., Chatterton, J.B., Coker, A. \& Green, C.: 2003, The Benefits of Flood and Coastal Defence: Techniques and Data for 2003. Flood Hazard Research Centre, Middlesex University, London.

Pringle, A.W.: 1985, 'Holderness coast erosion and the significance of ords', Earth Surface Processes and Landforms, 10:107-124

Reeve, D. E. and Burgess, K. A.: 1993, 'A method for the assessment of coastal flood risk', IMA Journal of Mathematics Applied in Business \& Industry, 5:197-209

Richards, J. Mokrech, M., Nicholls, R. J., Dawson, R. J., Hall, J. W. Walkden, M. J. A., Dickson, M. E., Bates, P., Jordan, A. and Milligan, J.: 2005, Assessing coastal flood risk at specific sites and regional scales: Regional assessment of coastal flood risk, Tyndall Centre Technical Report, October 2005.

RICS: 2003, Rural land market survey Great Britain: Second Quarter 2003, Royal Institution of Chartered Surveyors, London.

RIKZ, UNESCO-IHE and CRC: 2005, ICZM in practice with examples from different countries, RIKZ Workdocument nr. RIKZ/KW/2005.102w.

Rossiter, J. R.: 1954, 'The North Sea storm surge of 31st January and 1st February 1953’, Proc. Phil. Trans. Royal Soc. Series A, A246(915), 317-400.

Royal Haskoning: 2003, Winterton Dunes: Coastal Habitat Management Plan, English Nature and Environment Agency.

Royal Society: 1983, Risk Assessment, London: The Royal Society.

Royal Society: 1992, Risk: Analysis, Perception and Management, London: The Royal Society.

Sciberras, A. M.: 2002, 'Integrated Coastal Zone Management - A challenge for the EU in the 21st Century', EIPASCOPE, 2002(1), 1-5.

Shennan, I. and Horton, B.: 2002, ‘Holocene land- and sea-level changes in Great Britain’, Journal of Quaternary Science. 17:511-526. 
Small, C. \& Nicholls, R.J.: 2003, ‘A Global Analysis of Human Settlement in Coastal Zones’, Journal of Coastal Research, 19(3), 584-599.

Stansby P.K., Zhou J.G., Kuang C.P., Walkden M.J.A., Hall J.W. and Dickson M.E.: 2006, 'Longterm prediction of nearshore wave climate with an application to cliff erosion', in Proc $30^{\text {th }}$ Int. Conf. on Coastal Engineering, San Diego.

Steers, J.A.: 1953, ‘The East Coast Floods’, Geographical Journal 119(3), 280-295

Stewart, M. G. and Melchers, R. E.: 1997, Probabilistic Risk Assessment of Engineering Systems. Chapman and Hall.

Thomas, R. S. and Hall, B.: 1992, Seawall Design, CIRIA, London.

Thomalla, F. and Vincent, C. E.: 2003, 'Beach response to shore-parallel breakwaters at Sea Palling, Norfolk, UK', Estuarine, coastal and shelf science, 56(2), 203-212

Thorne, C., Evans, E. and Penning-Rowsell, E.: 2007, Future flooding and coastal erosion risks, Thomas Telford, London.

Turner, R. K., Subak, S. and Adger, W. N.: 1996, 'Pressures, trends, and impacts in coastal zones: interactions between socioeconomic and natural systems', Environmental Management, 20(2), 159173.

UKCIP: 2006, The UKCIPnext package of climate change information - what do users want?, UK Climate Impacts Programme, Interim report: 6 February 2006.

UN: 1994, United Nations Framework Convention on Climate Change, United Nations. Vellinga, P.: 1983, Verification of Predictive Computational Model for Beach and Dune Erosion During Storm Surges. Delft Hydraulics Laboratory.

Vincent, C.E.: 1979, 'Longshore sand transport rates - a simple model for the East Anglian coastline’, Coastal Engineering. 3:113-136.

Visser, P. J.: 1998, Breach growth in sand defences, Communication on hydraulic and geotechnical engineering, TU Delft Report no. 98-91.

VOA: 2003, Property Market Report, Valuation Office Agency, Spring 2003.

Wahl, T. L.: 1998, Prediction of embankment dam breach parameters: a literature review and needs assessment, Dams Safety Office: DSO-98-004.: www.usbr.gov/pmts/hydraulics_lab/twahl/). Walkden, M., and Dickson, M (2008) Equilibrium erosion of soft rock shores with a shallow or absent beach under increased sea level rise, Marine Geology. 251(1-2): 75-84. 
Walkden, M. J. A. and Hall, J. W.: 2005, 'A predictive mesoscale model of the erosion and profile development of soft rock shores’, Coastal Engineering. 52, 535-563.

Wright, M.: 2004, 'Coastal defence - current UK practice’, Proc. ICE: Municipal Engineer, 157:147-155. 


\section{Figure legends}

Figure 1 Location of the study area in eastern England, showing the location of the major settlements and land elevation. The area of cliff erosion is indicated by the dotted line.

Figure 2 Beach at Winterton with concrete sea wall in front of sand dune on 31st October 2003 (the detached breakwaters are just visible on the horizon)

Figure 3 Land use and location of settlements (Grades correspond to those in Table 3)

Figure 4 Overview of the assessment methodology, including the role of the scenarios

Figure 5 Wave transformation modelling domain showing the bathymetry (metres below Ordnance Datum) off the East Anglian coastline

Figure 6 Location of SCAPE model sections for simulating the long term morphological response of the coast illustrating the major morphological features

Figure 7 Diagrammatic representation of the coastal landsliding model. The parameters are described in the text.

Figure 8 The four socio-economic scenarios (DTI, 2002) used to explore the impacts of socioeconomic change on flood and erosion risk.

Figure 9 (a) Total recession predicted along the cliffed frontage under scenarios 15, 24 \& 33 with 71, 34 and 16\% coastal protection respectively, (b) recession distances under scenario 33 in 10 year timesteps. The letters $H, B, M, T, O, C$ and $S$ represent the locations of Happisburgh, Bacton, Mundesley, Trimingham, Overstrand and Sheringham respectively.

Figure 10. Beach volumes $(\mathrm{m} 3 / \mathrm{m})$ to 2100 predicted under scenario 33 for the coastline north of Winterton. The letters on the vertical axes represent the locations of the settlements and the right hand bar provides the scale. 
Figure 11 Histogram of average annual beach volumes from 2020-2100 for scenarios 15, 24 and 33 with 71, 34 and 16\% coastal protection respectively. There is increased variability in beach volume along the coast when more engineering structures are present.

Figure 12 Time series of annual flood probability (for a water depth greater than $0 \mathrm{~m}$ ) for low, med and high sea-level rise (Scenarios 10, 14 and 15) at E:645075, N:322775 just inland of the midpoint between Sea Palling and Winterton Ness

Figure 13 The influence of beach morphology on defence failure probability for a flood defence in front of the Norfolk broads for Scenario 19

Figure 14 Map of most probable (i.e. maxima of the p.d.f. $\left.f_{c}(x \mid x s, y, t)\right)$ described in Equation 1) cliff top erosion extent (metres) and the annual probability of flooding (to a depth of greater than $0 \mathrm{~m}$ ) for (a) in 2003 and (b) in 2100 for Scenario 15 with high sea-level rise and 71\% of the coast protected. Darker shades imply greater probability of recession and flooding.

Figure 15 Comparison of the evolution of (a) erosion and (b) flood risks over the 21st Century under a high climate change scenario and assuming no change in socio-economic vulnerability: Scenarios 6, 15, 24, 33, 42 (Note: (a) and (b) are plotted to different scales) represent decreasing levels of cliff protection.

Figure 16 Map of flood and erosion risks, expressed in terms of expected annual damages (a) at present and (b) in 2100 for Scenario 15 with constant socio-economic conditions. The cliff erosion risk has been scaled to the area of a flood cell $(250 \mathrm{~m} \times 250 \mathrm{~m})$. Darker shades imply a greater risk.

Figure 17 The effect of sea-level rise on the evolution of flood risk over the 21st Century for Scenarios 10, 14 and 15 (low, medium and high respectively) assuming no socio-economic change

Figure 18 Net present risks for each combination of management and socio-economic scenario clustered according to climate scenarios (see Table 2 for details)

Figure 19 Virtual reality visualisation of coasts (each line represents a 10 year central estimate of the cliff toe position) 


\section{Table legend}

Table 1 Return periods for extreme water levels (mAOD) at Cromer and Great Yarmouth (Dixon and Tawn, 1997)

\begin{tabular}{|c|c|c|}
\hline $\begin{array}{c}\text { Return Period } \\
\text { (Year) }\end{array}$ & Cromer & Great Yarmouth \\
\hline 10 & 3.78 & 2.74 \\
\hline 50 & 4.12 & 3.08 \\
\hline 100 & 4.33 & 3.3 \\
\hline 250 & 4.53 & 3.51 \\
\hline 1000 & 4.82 & 3.8 \\
\hline
\end{tabular}

Table 2 Scenario numbering scheme for the coastal management and climate change combinations considered in this study. '+' and '-' indicate rotation of the wave rose by 10 degrees clockwise and anticlockwise respectively; percentages indicate proportions of cliffed coast protected by structures. The italicised scenarios are those that are explored in more detail in this paper.

\begin{tabular}{|c|cccc|c|cccc|}
\hline Management & \multicolumn{6}{|c|}{ Wave $\left(H_{s}\right.$ ) and sea-level rise (SLR) climate scenario } \\
scenario & \multicolumn{4}{|c}{ Low SLR } & Med SLR & \multicolumn{4}{c|}{ High SLR } \\
(\% coast & $\boldsymbol{H}_{\boldsymbol{s}}$ & $\boldsymbol{H}_{\boldsymbol{s}}$ & $\boldsymbol{H}_{\boldsymbol{s}}$ & $\boldsymbol{H}_{\boldsymbol{s}}$ & $\boldsymbol{H}_{\boldsymbol{s}}$ & $\boldsymbol{H}_{\boldsymbol{s}}$ & $\boldsymbol{H}_{\boldsymbol{s}}$ & $\boldsymbol{H}_{\boldsymbol{s}}$ & $\boldsymbol{H}_{\boldsymbol{s}}$ \\
protected) & low & high & high + & high - & mid & low & high & high + & high - \\
A (100\%) & 1 & 2 & 3 & 4 & 5 & $\mathbf{6}$ & 7 & 8 & 9 \\
B (71\%) & $\mathbf{1 0}$ & 11 & 12 & $\mathbf{1 3}$ & $\mathbf{1 4}$ & $\mathbf{1 5}$ & 16 & 17 & 18 \\
C (34\%) & $\mathbf{1 9}$ & 20 & 21 & 22 & 23 & $\mathbf{2 4}$ & 25 & 26 & 27 \\
D (16\%) & 28 & 29 & 30 & 31 & 32 & 33 & 34 & 35 & 36 \\
E (0\%) & 37 & 38 & 39 & 40 & 41 & $\mathbf{4 2}$ & 43 & 44 & 45 \\
\hline
\end{tabular}


Table 3 Losses by area for different classes of agricultural land at 2003 prices (erosion losses of agricultural land are reduced by $45 \%$ to account for government subsidies)

\begin{tabular}{|c|c|c|}
\hline Land grade & $\begin{array}{c}\text { Inundation losses ( } £ / h a) \\
\text { (Penning-Rowsell et al., 2003) }\end{array}$ & $\begin{array}{c}\text { Erosion value (£/ha) } \\
\text { (RICS, 2003) }\end{array}$ \\
\hline 1 - Arable & 1,160 & 5,683 \\
\hline 2 & 770 & 5,683 \\
\hline 3a & 400 & 5,683 \\
\hline $3 \mathbf{b}$ & 160 & 5,683 \\
\hline 4 & 50 & 4,571 \\
\hline 5 - Unfarmable & 20 & 4,571 \\
\hline
\end{tabular}




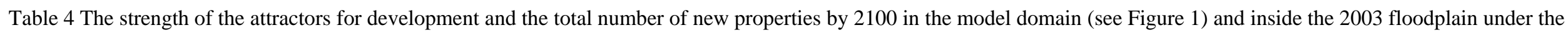
four socio-economic scenarios. In 2003 the area at risk of flooding contained 16,766 residential properties (RP) and 3160 non-residential properties (NRP).

\begin{tabular}{|c|c|c|c|c|c|}
\hline \multicolumn{2}{|l|}{ Scenario } & $\begin{array}{c}\text { Local } \\
\text { Stewardship }\end{array}$ & $\begin{array}{c}\text { Global } \\
\text { Responsibility }\end{array}$ & $\begin{array}{l}\text { National } \\
\text { Enterprise }\end{array}$ & $\begin{array}{l}\text { World } \\
\text { Markets }\end{array}$ \\
\hline \multicolumn{2}{|l|}{ Ratio of non-residential to residential property } & $-10 \%$ & $0 \%$ & $0 \%$ & $10 \%$ \\
\hline \multirow[t]{4}{*}{ Attractor/Repulsor factor } & Settlements & $1 / 16$ & 8 & 1 & 1 \\
\hline & Transport & $1 / 8$ & 1 & 1 & 8 \\
\hline & Coast & $1 / 8$ & 8 & 8 & 16 \\
\hline & Floodplains & $1 / 16$ & $1 / 8$ & 8 & 16 \\
\hline \multirow{2}{*}{$\begin{array}{l}\text { Number of new properties in model } \\
\text { domain shown in Figure } 2 \text { by } 2100\end{array}$} & $\mathbf{R P}$ & 62,607 & 98,158 & 136,053 & 171,790 \\
\hline & NRP & 4,069 & 9,939 & 13,785 & 19,662 \\
\hline \multirow[t]{2}{*}{ New properties in the floodplain } & $\mathbf{R P}$ & 1343 & 10,882 & 19,550 & 19,719 \\
\hline & NRP & 80 & 1,082 & 1,908 & 2,127 \\
\hline \multirow{2}{*}{$\begin{array}{l}\text { Number of new properties within } 400 \mathrm{~m} \text { of } \\
\text { cliff top }\end{array}$} & $\mathbf{R P}$ & 330 & 511 & 654 & 787 \\
\hline & NRP & 17 & 44 & 52 & 85 \\
\hline
\end{tabular}




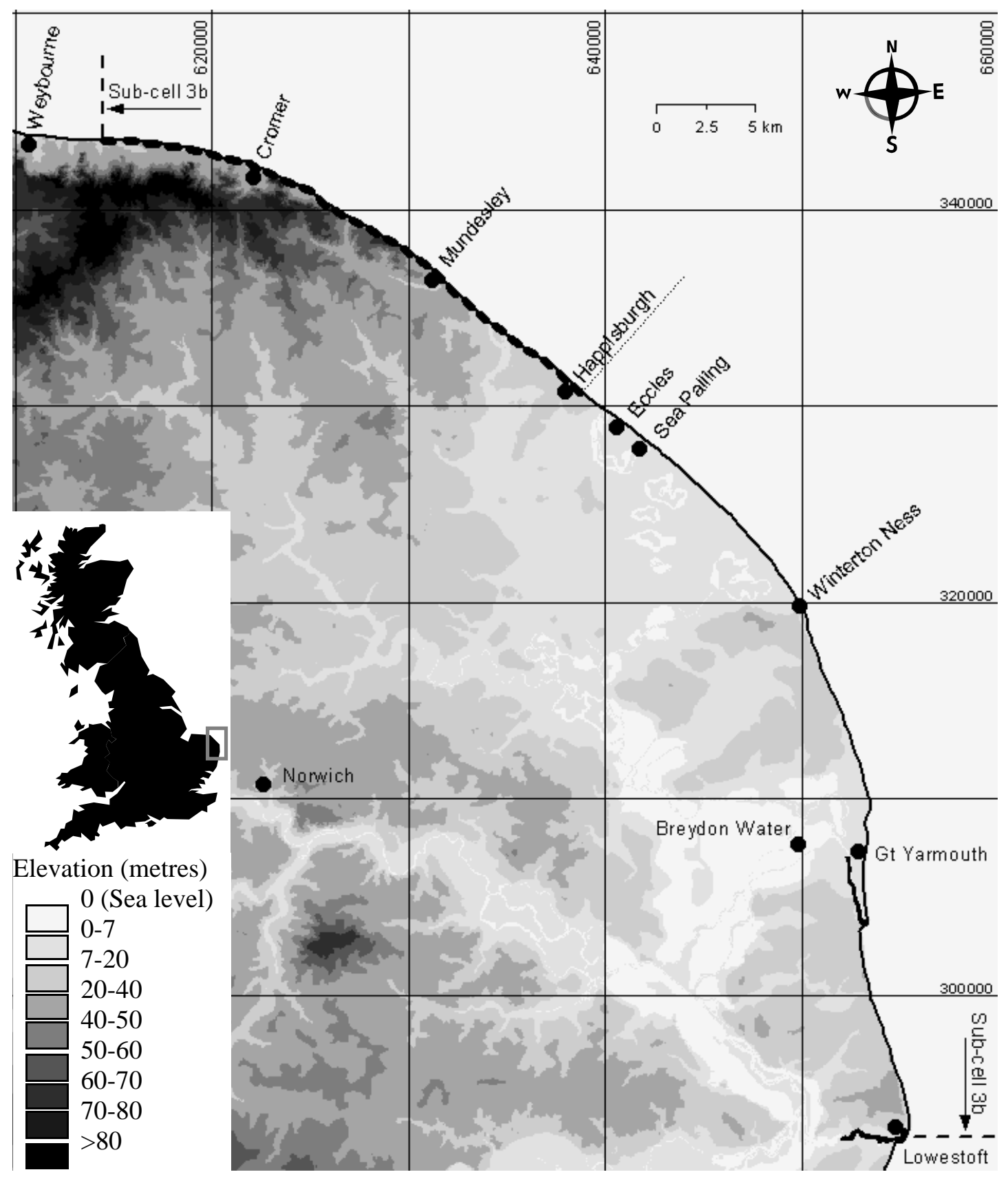

Figure 1 Location of the study area in eastern England, showing the location of the major settlements and land elevation. The area of cliff erosion is indicated by the dotted line. 


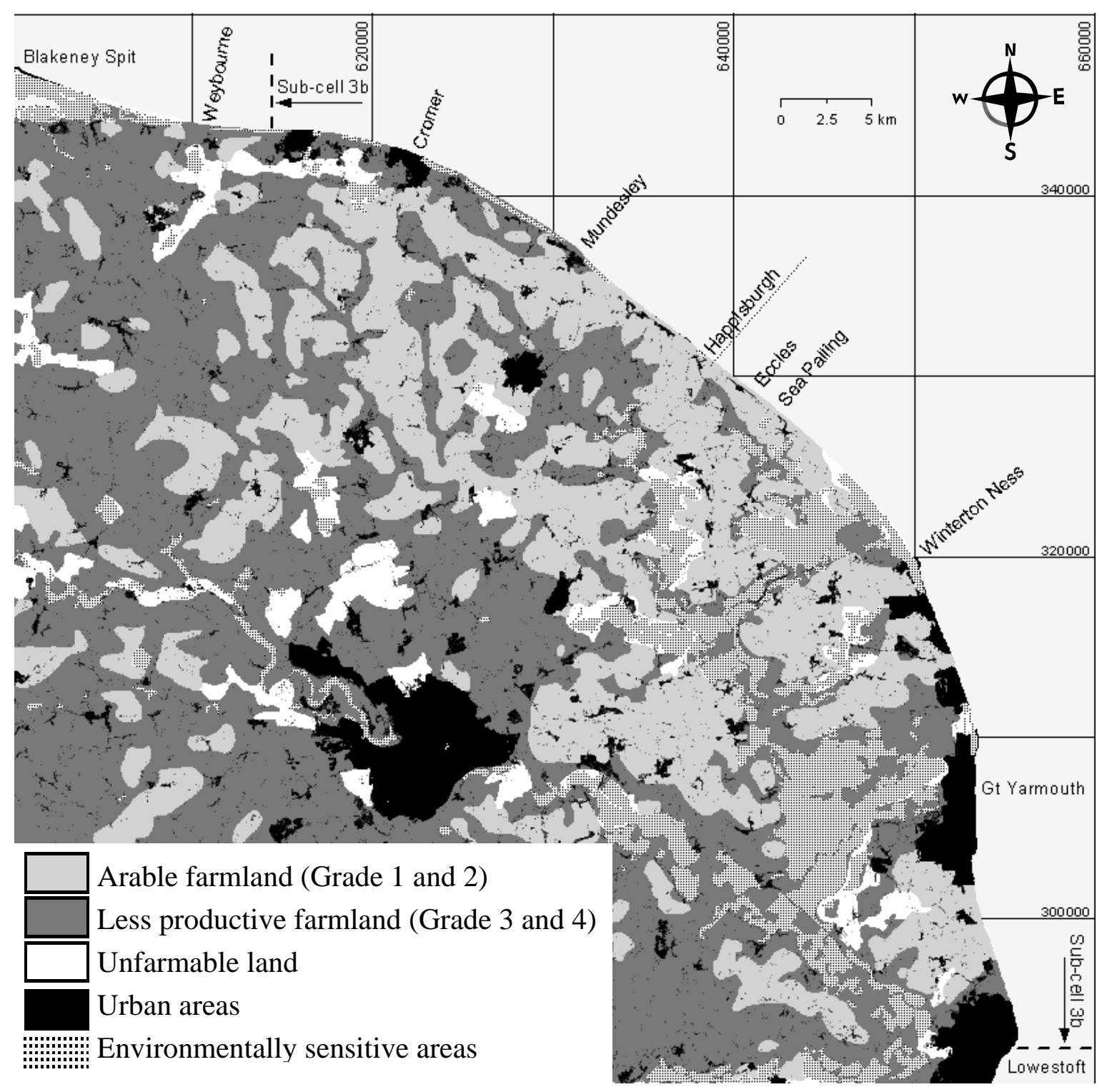

Figure 3 Land use and location of settlements (Grades correspond to those in Table 3) 


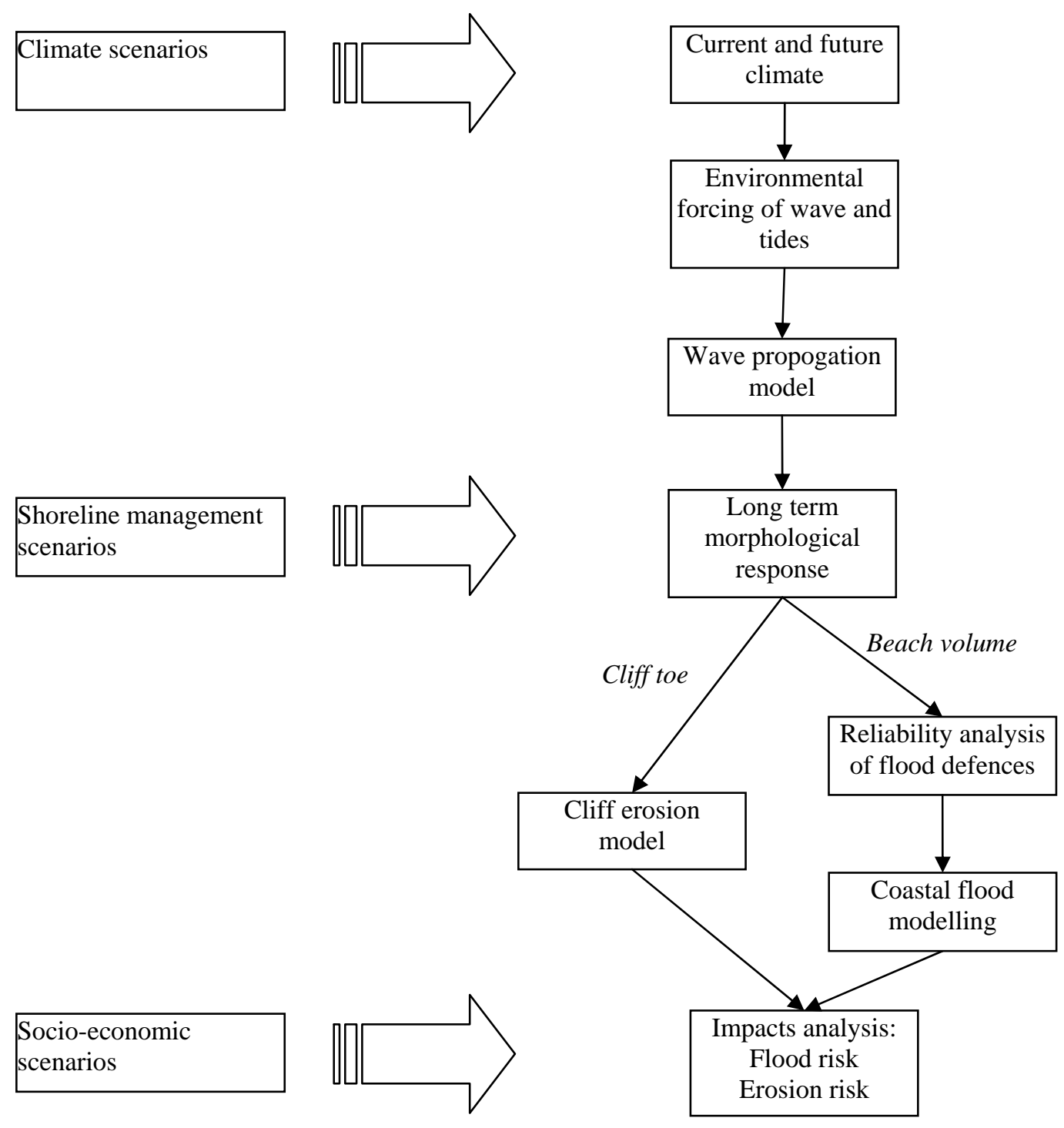

Figure 4 Overview of the assessment methodology, including the role of the scenarios 


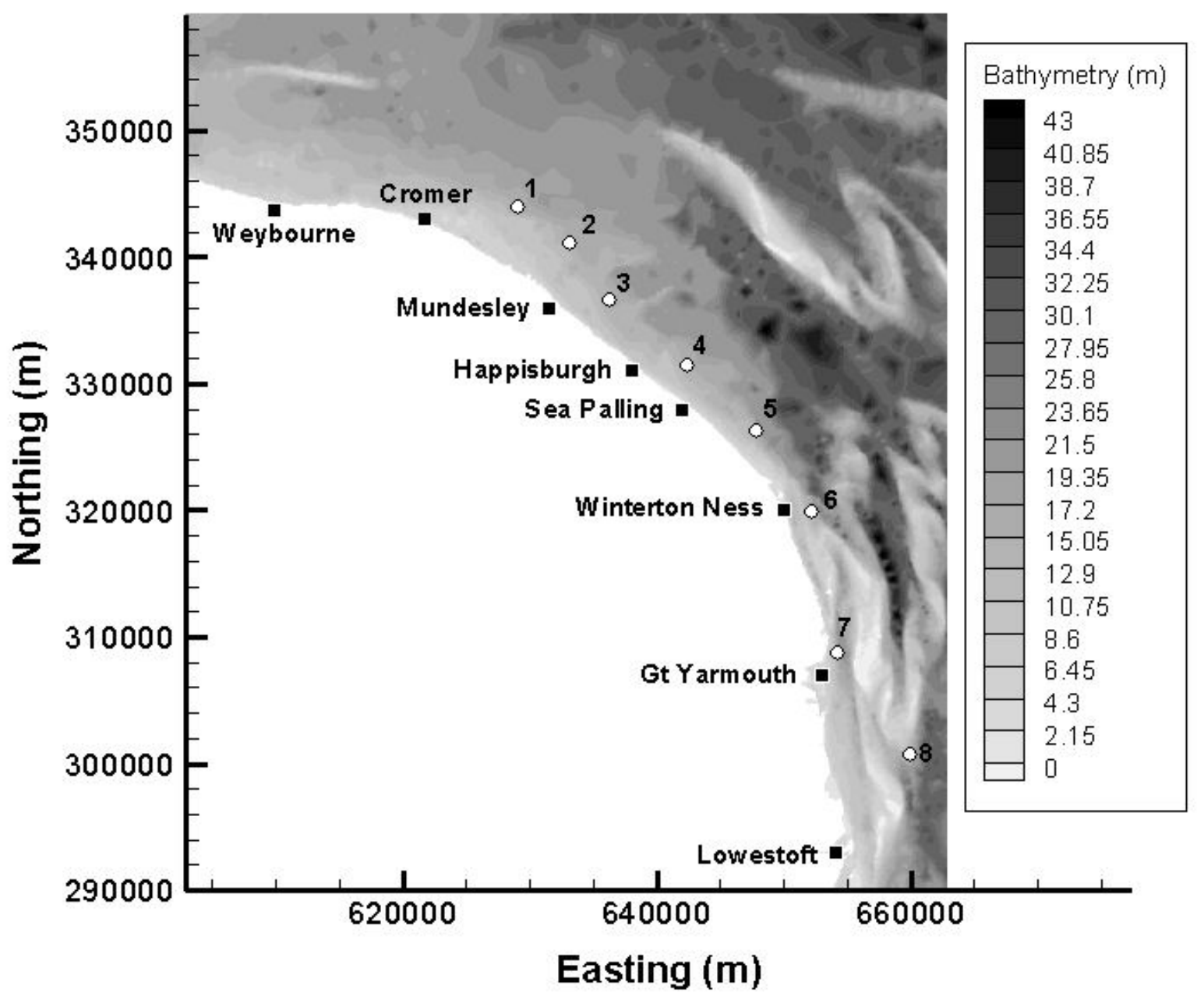

Figure 5 Wave transformation modelling domain showing the bathymetry (metres below Ordnance Datum) off the East Anglian coastline 


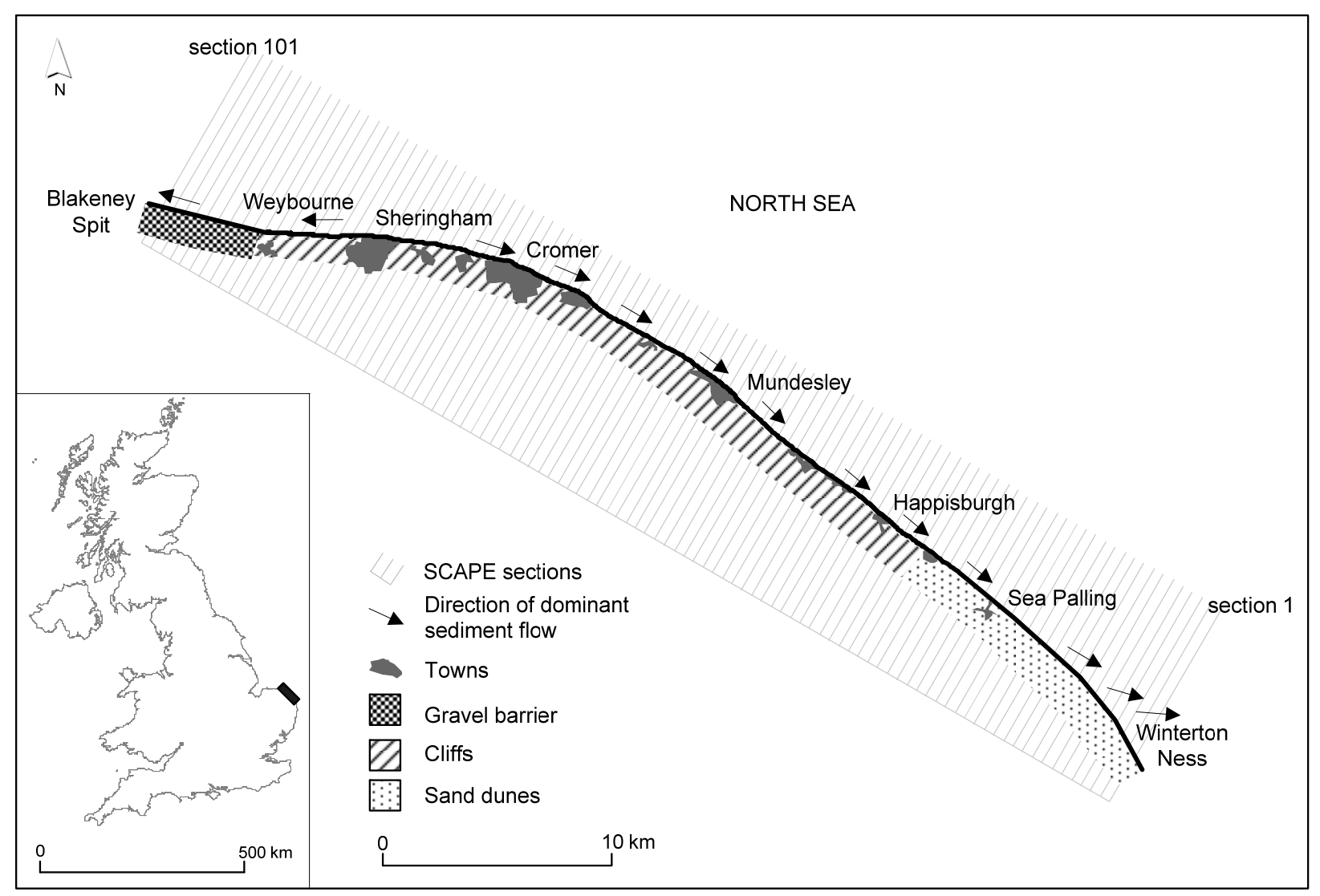

Figure 6 Location of SCAPE model sections for simulating the long term morphological response of the coast illustrating the major morphological features 


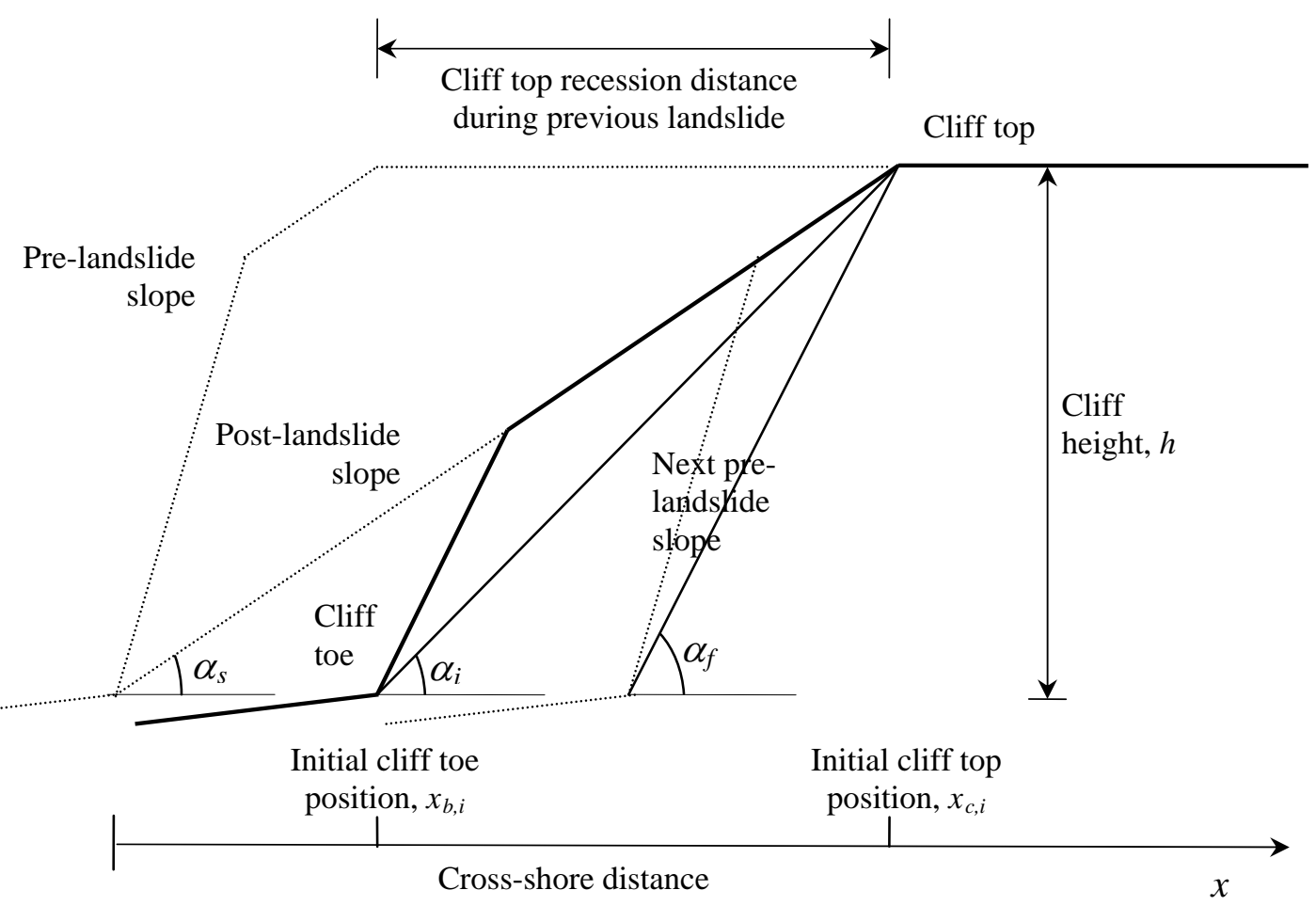

Figure 7 Diagrammatic representation of the coastal landsliding model. The parameters are described in the text. 


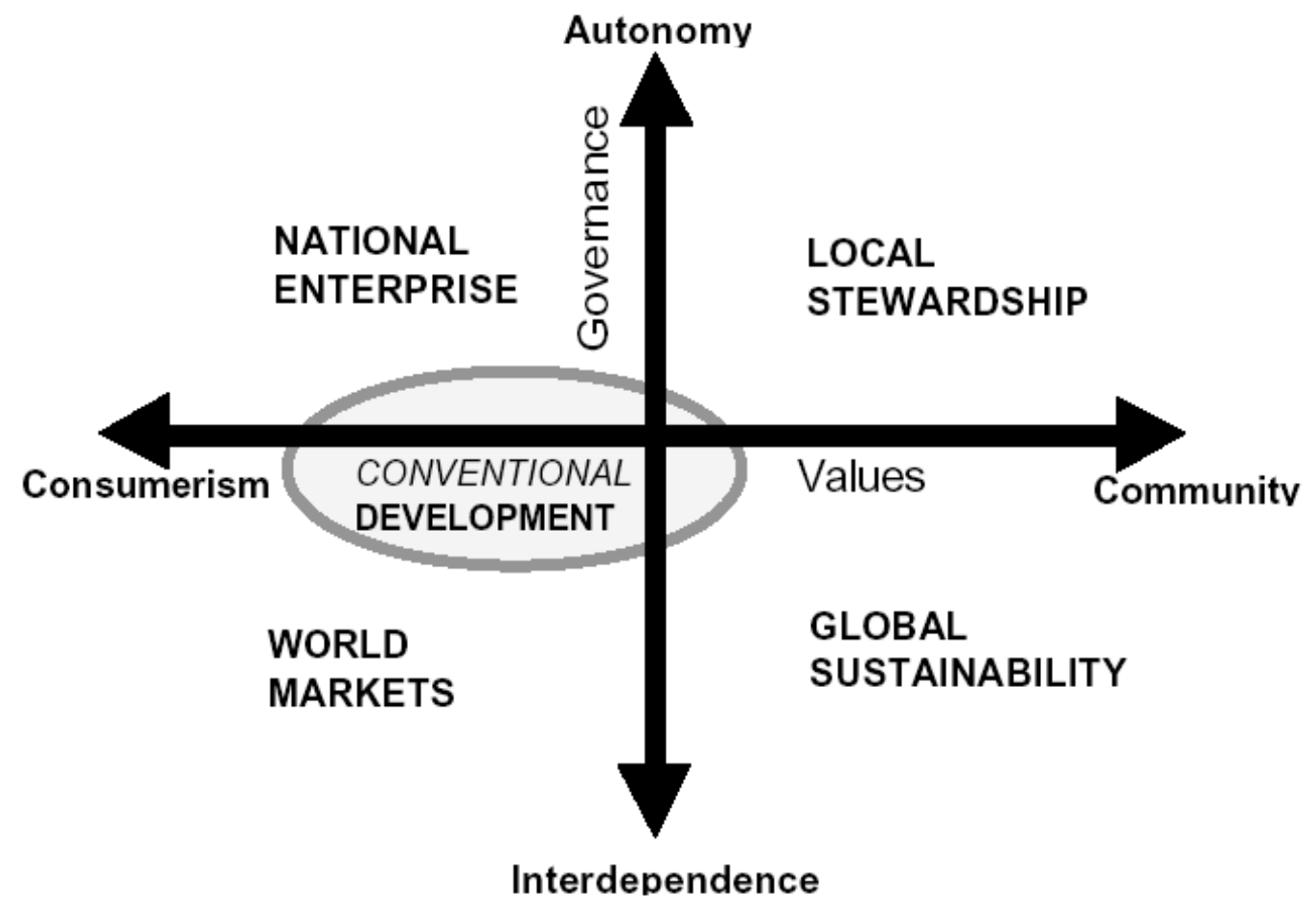

Figure 8 The four socio-economic scenarios (DTI, 2002) used to explore the impacts of socioeconomic change on flood and erosion risk. 


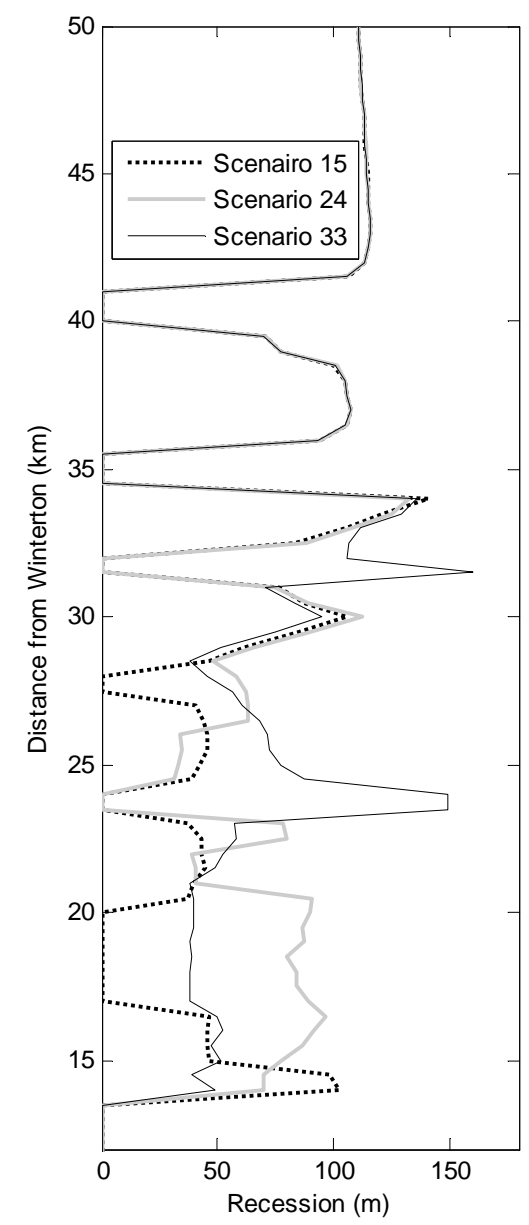

(a)

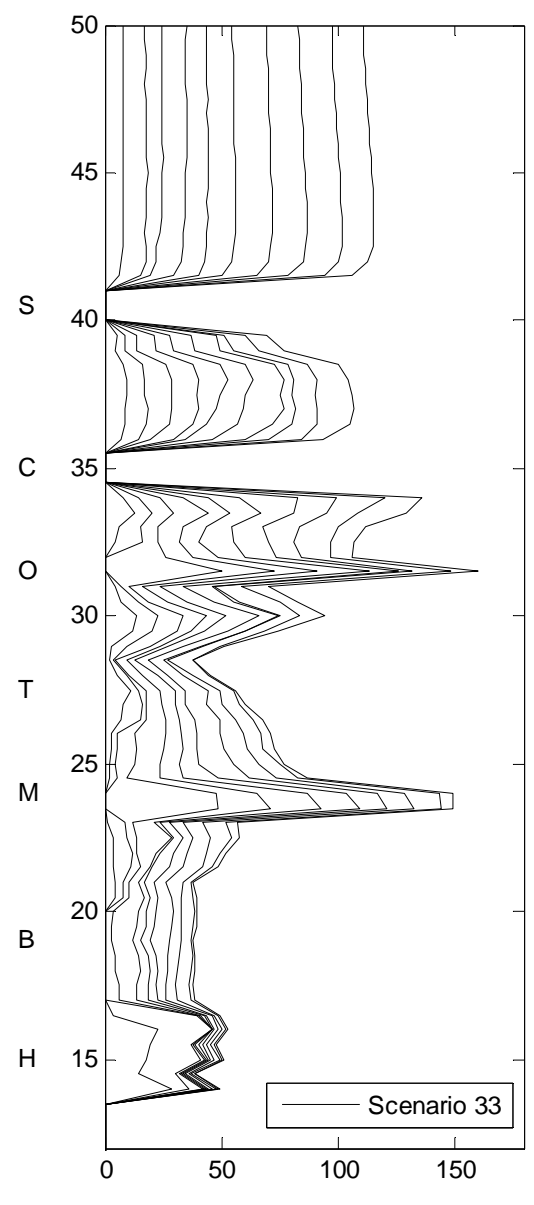

(b)

Figure 9 (a) Total recession predicted along the cliffed frontage under scenarios 15, 24 \& 33 with 71, 34 and 16\% coastal protection respectively, (b) recession distances under scenario 33 in 10 year timesteps. The letters H, B, M, T, O, C and S represent the locations of Happisburgh, Bacton, Mundesley, Trimingham, Overstrand and Sheringham respectively. 


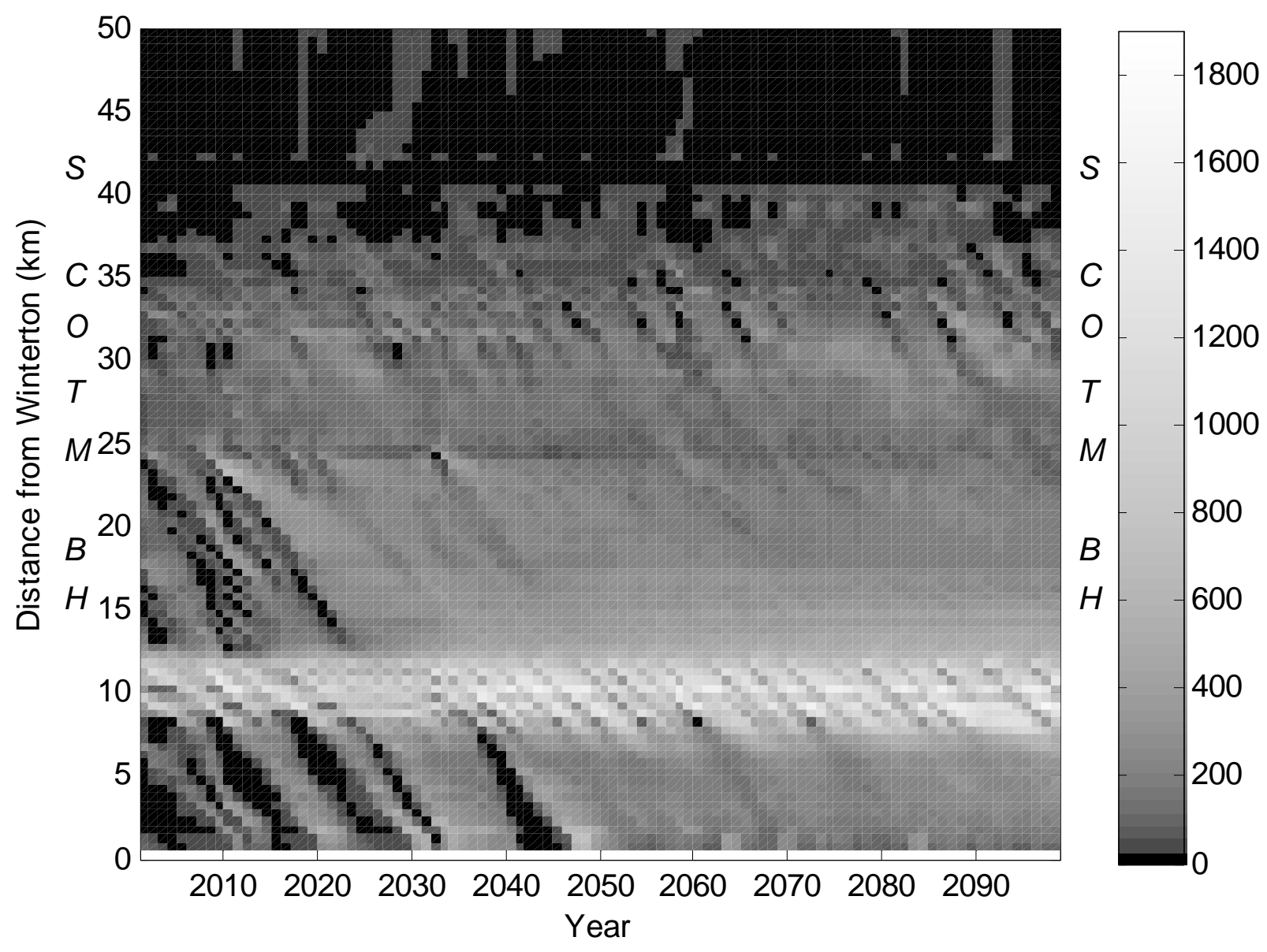

Figure 10. Beach volumes $(\mathrm{m} 3 / \mathrm{m})$ to 2100 predicted under scenario 33 for the coastline north of Winterton. The letters on the vertical axes represent the locations of the settlements and the right hand bar provides the scale. 


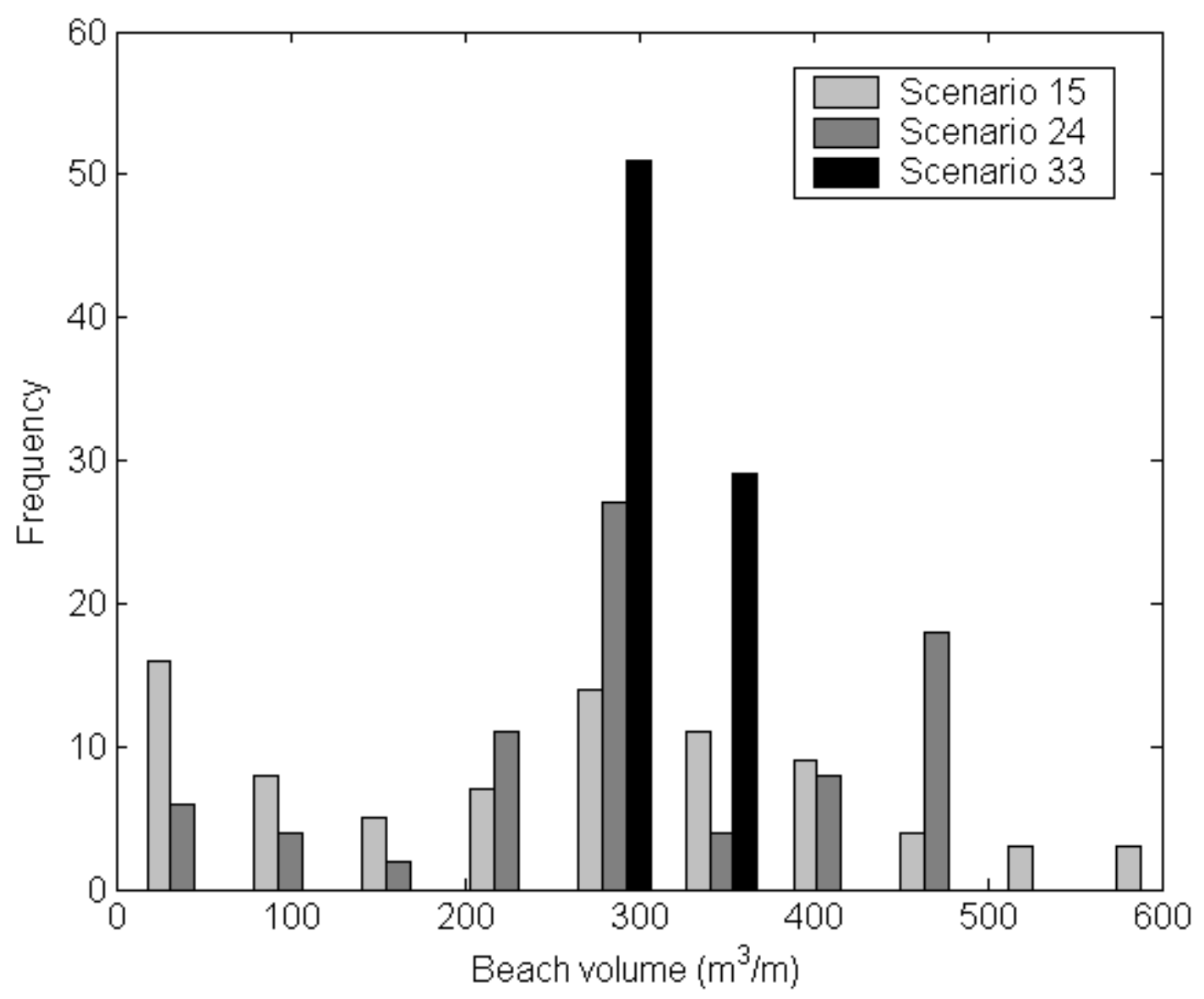

Figure 11 Histogram of average annual beach volumes from 2020-2100 for scenarios 15, 24 and 33 with 71,34 and $16 \%$ coastal protection respectively. There is increased variability in beach volume along the coast when more engineering structures are present. 


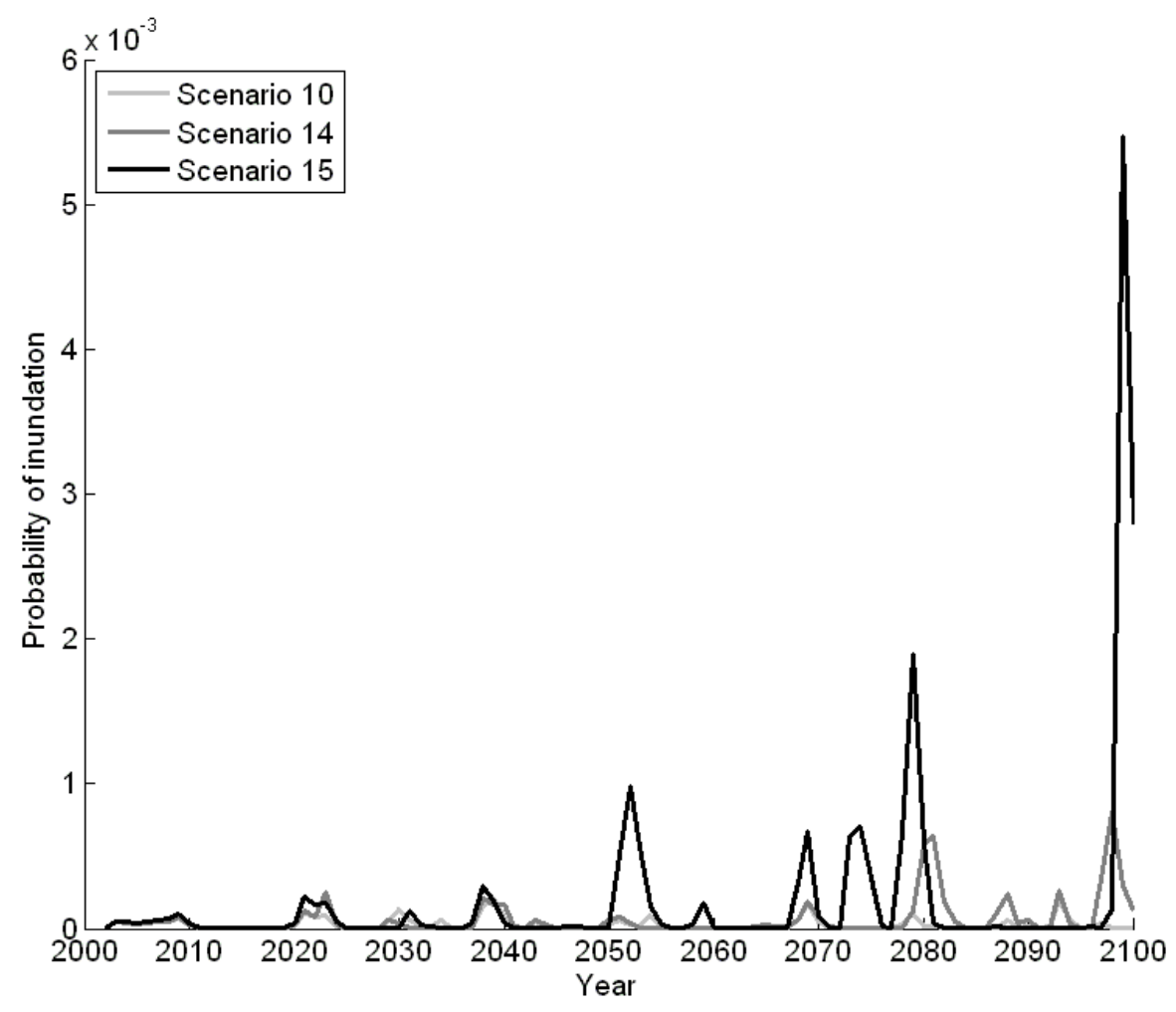

Figure 12 Time series of annual flood probability (for a water depth greater than $0 \mathrm{~m}$ ) for low, med and high sea-level rise (Scenarios 10, 14 and 15) at E:645075, N:322775 just inland of the midpoint between Sea Palling and Winterton Ness 

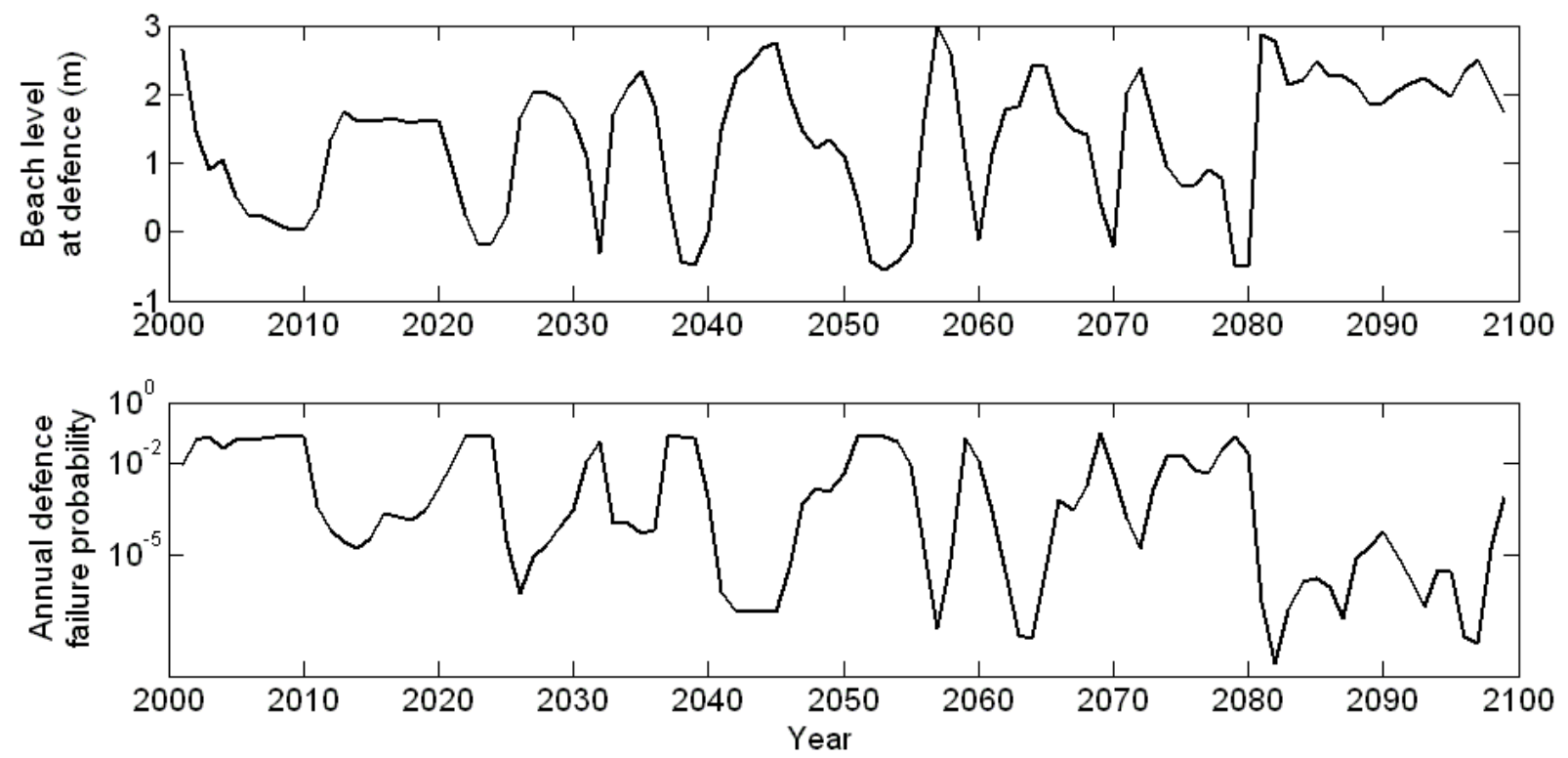

Figure 13 The influence of beach morphology on defence failure probability for a flood defence in front of the Norfolk broads for Scenario 19 


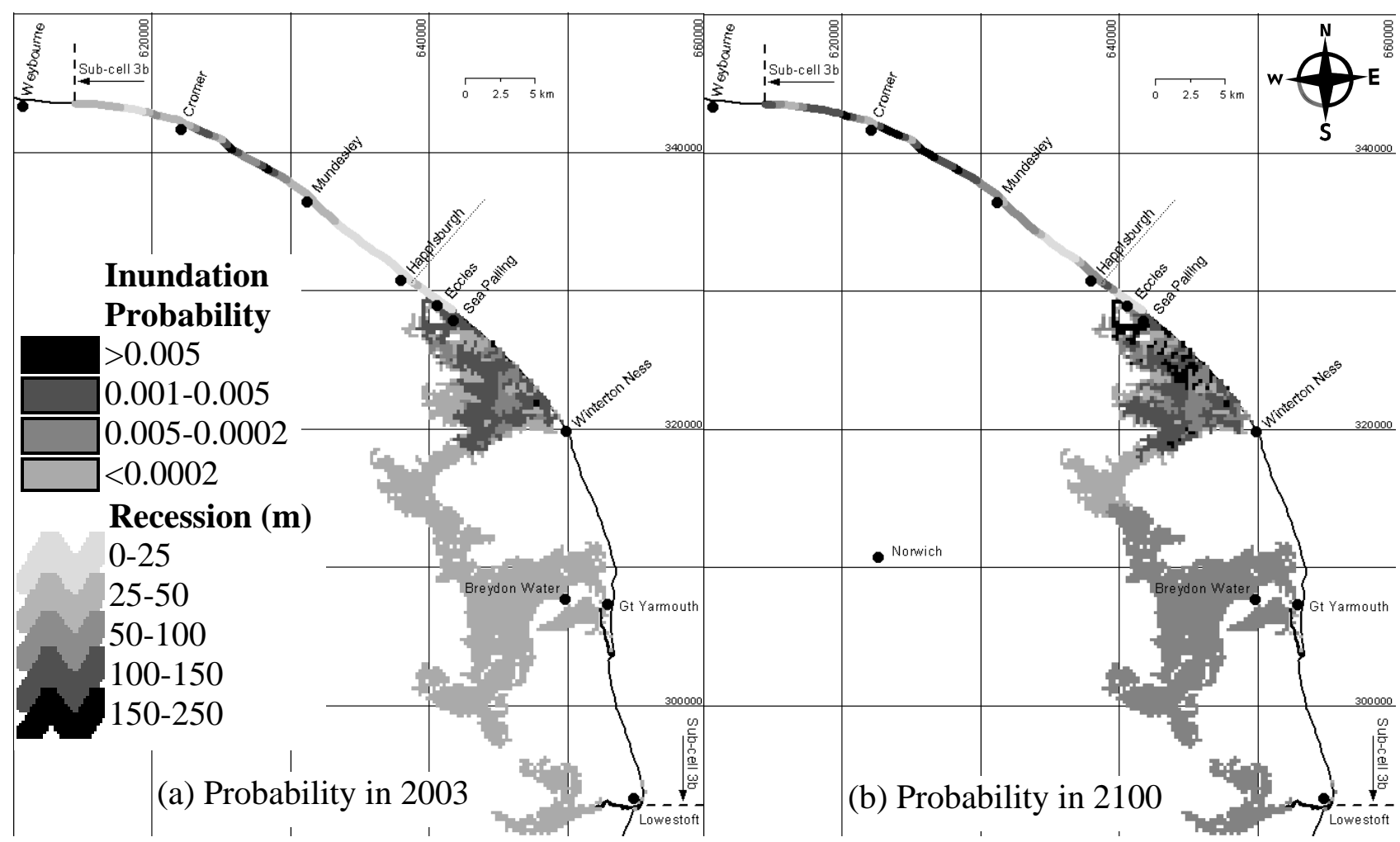

Figure 14 Map of most probable (i.e. maxima of the p.d.f. $\mathrm{fc}(\mathrm{x} \mid \mathrm{xs}, \mathrm{y}, \mathrm{t}))$ described in Equation 1) cliff top erosion extent (metres) and the annual probability of flooding (to a depth of greater than $0 \mathrm{~m}$ ) for (a) in 2003 and (b) in 2100 for Scenario 15 with high sea-level rise and 71\% of the coast protected. Darker shades imply greater probability of recession and flooding. 

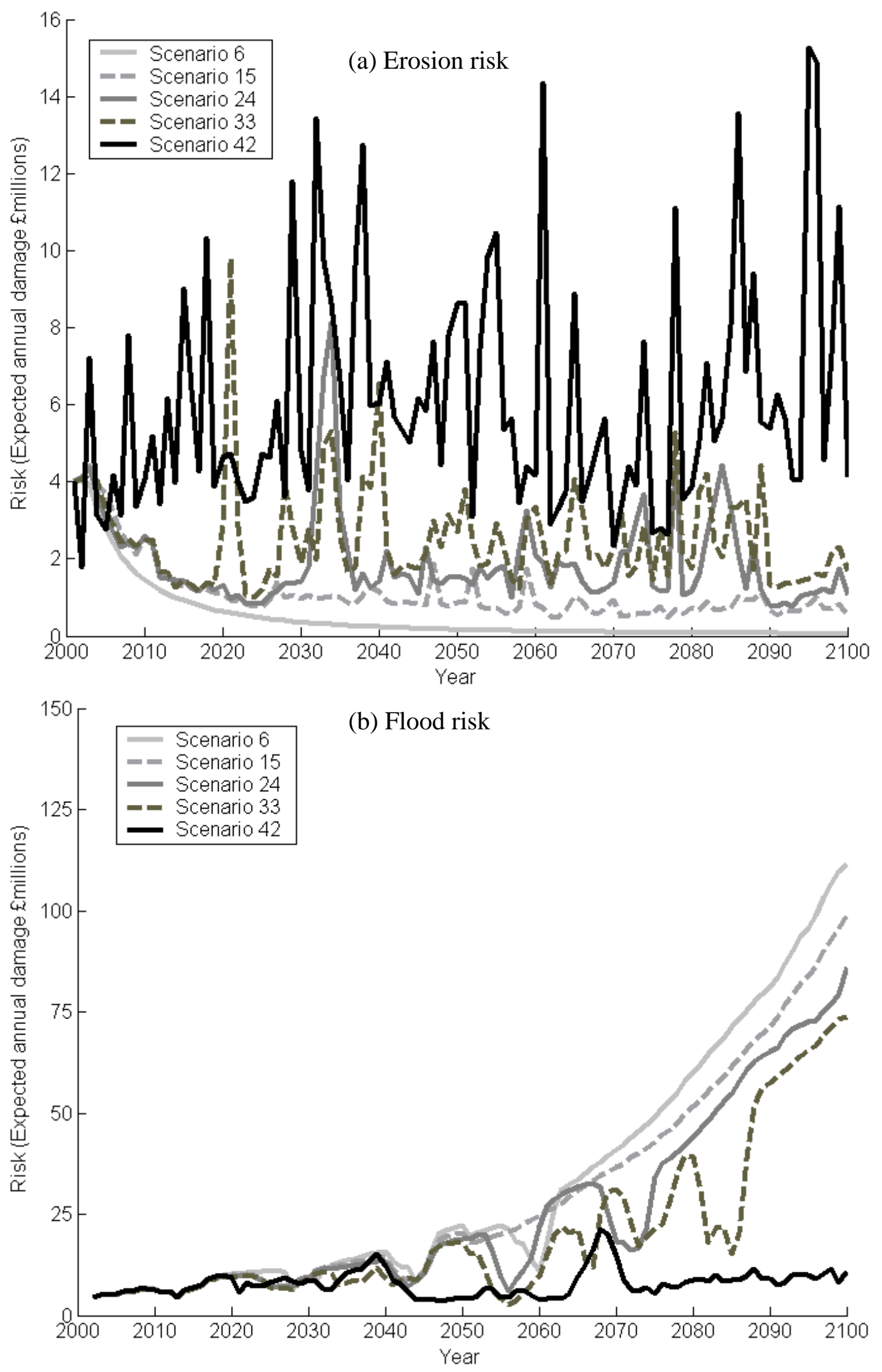

Figure 15 Comparison of the evolution of (a) erosion and (b) flood risks over the 21st Century under a high climate change scenario and assuming no change in socio-economic vulnerability: Scenarios 6, 15, 24, 33, 42 (Note: (a) and (b) are plotted to different scales) represent decreasing levels of cliff protection. 


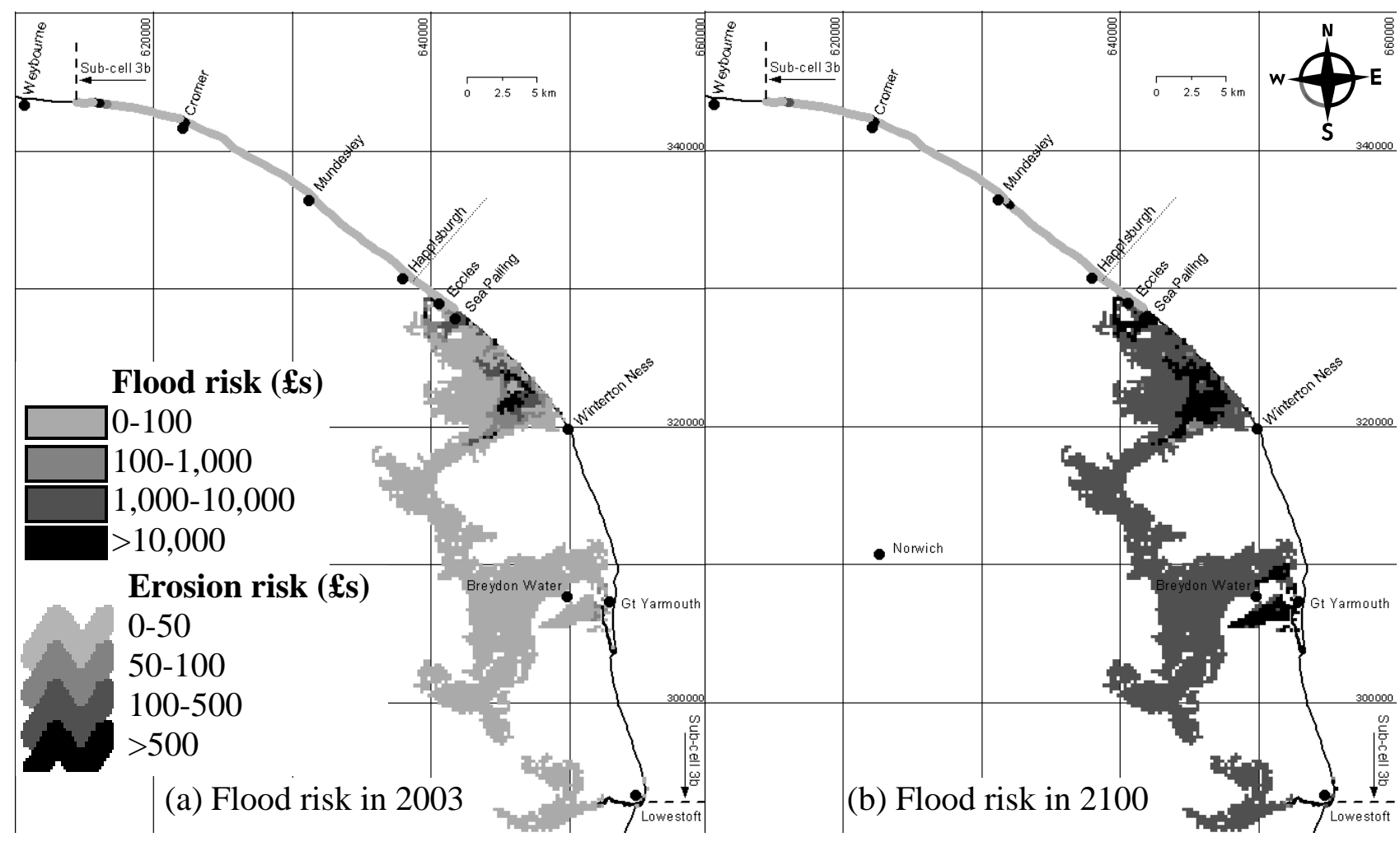

Figure 16 Map of flood and erosion risks, expressed in terms of expected annual damages (a) at present and (b) in 2100 for Scenario 15 with constant socio-economic conditions. The cliff erosion risk has been scaled to the area of a flood cell $(250 \mathrm{~m} \times 250 \mathrm{~m})$. Darker shades imply a greater risk. 


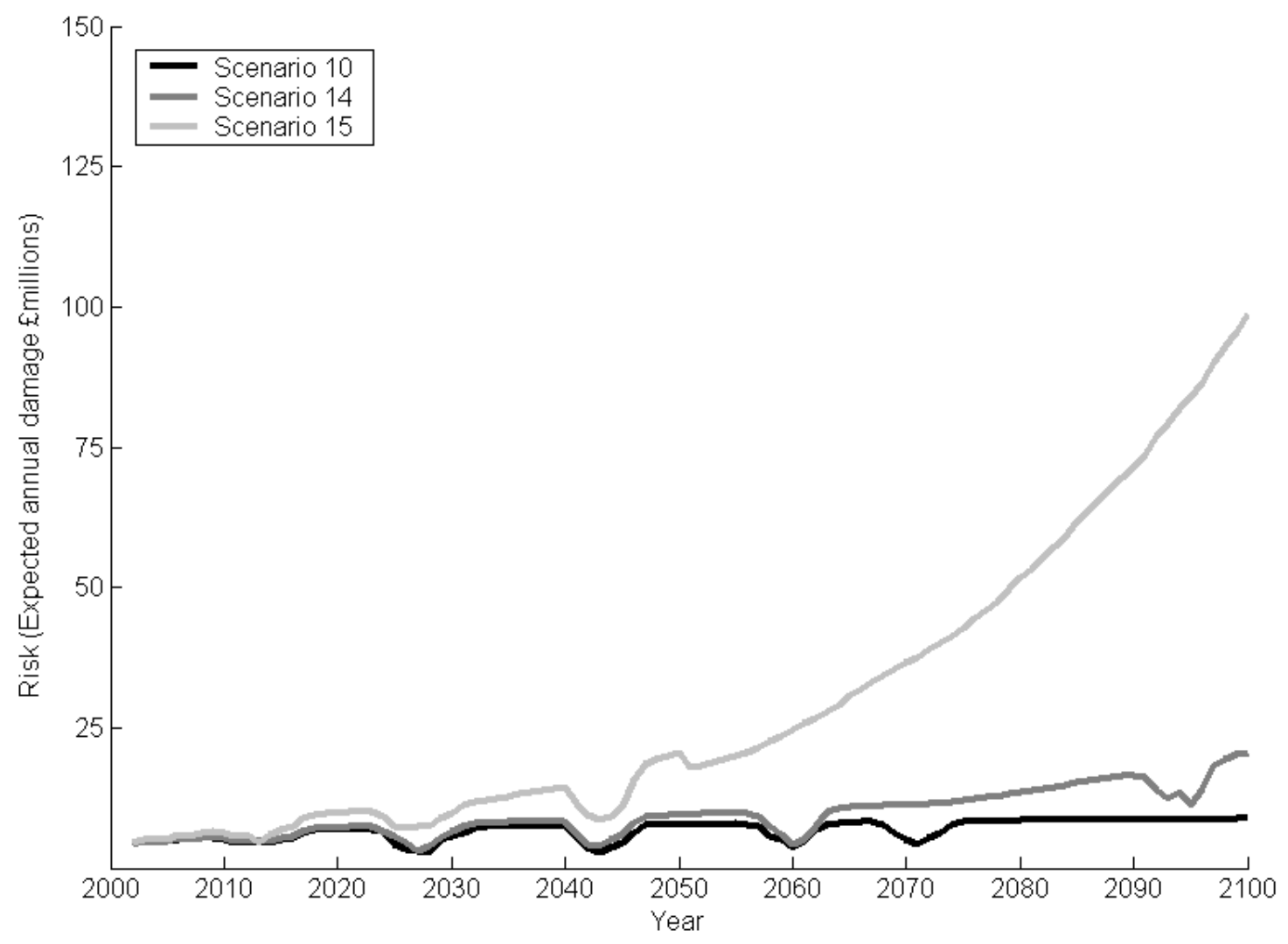

Figure 17 The effect of sea-level rise on the evolution of flood risk over the 21st Century for Scenarios 10, 14 and 15 (low, medium and high respectively) assuming no socio-economic change 


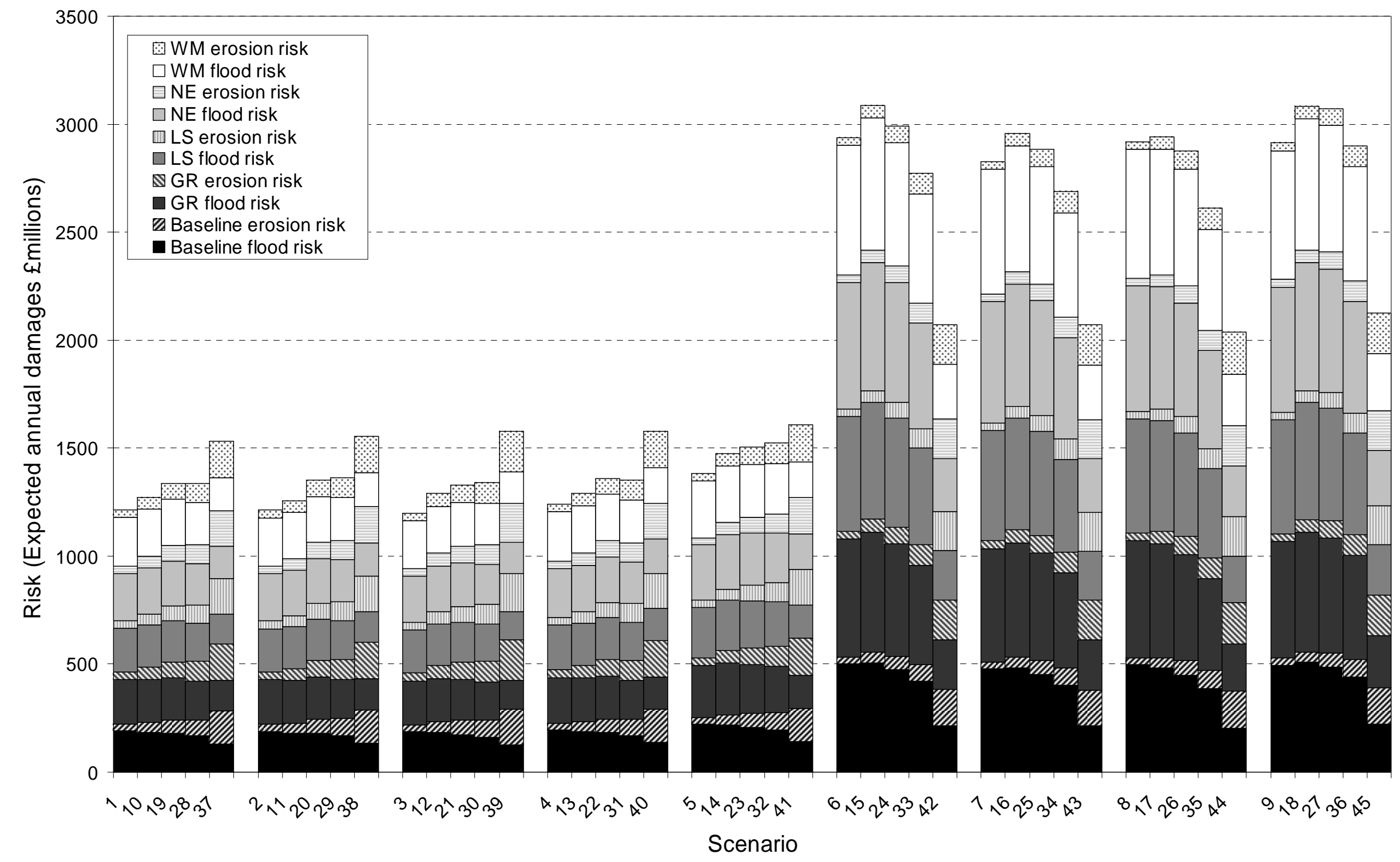

Figure 18 Net present risks for each combination of management and socio-economic scenario clustered according to climate scenarios (see Table 2 for details) 
tald

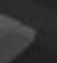

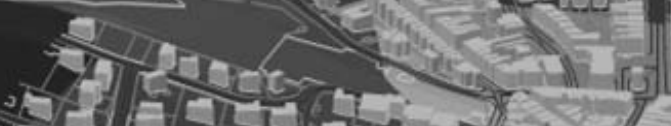

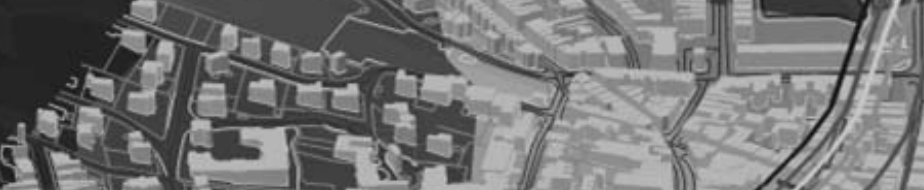

$\left.4^{2}\left(\frac{-3}{x^{2}}\right)^{-1}-4\right)$

1 1) $\mathrm{mat}$

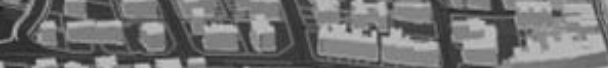

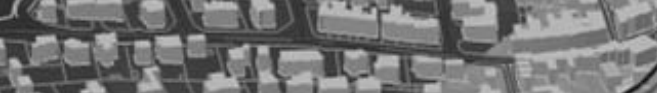

bes tugt

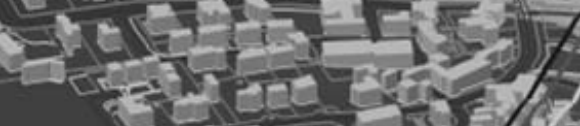

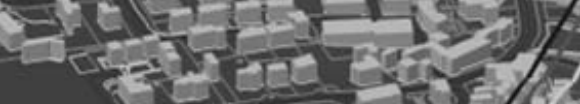

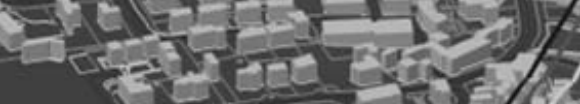

catere?

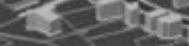
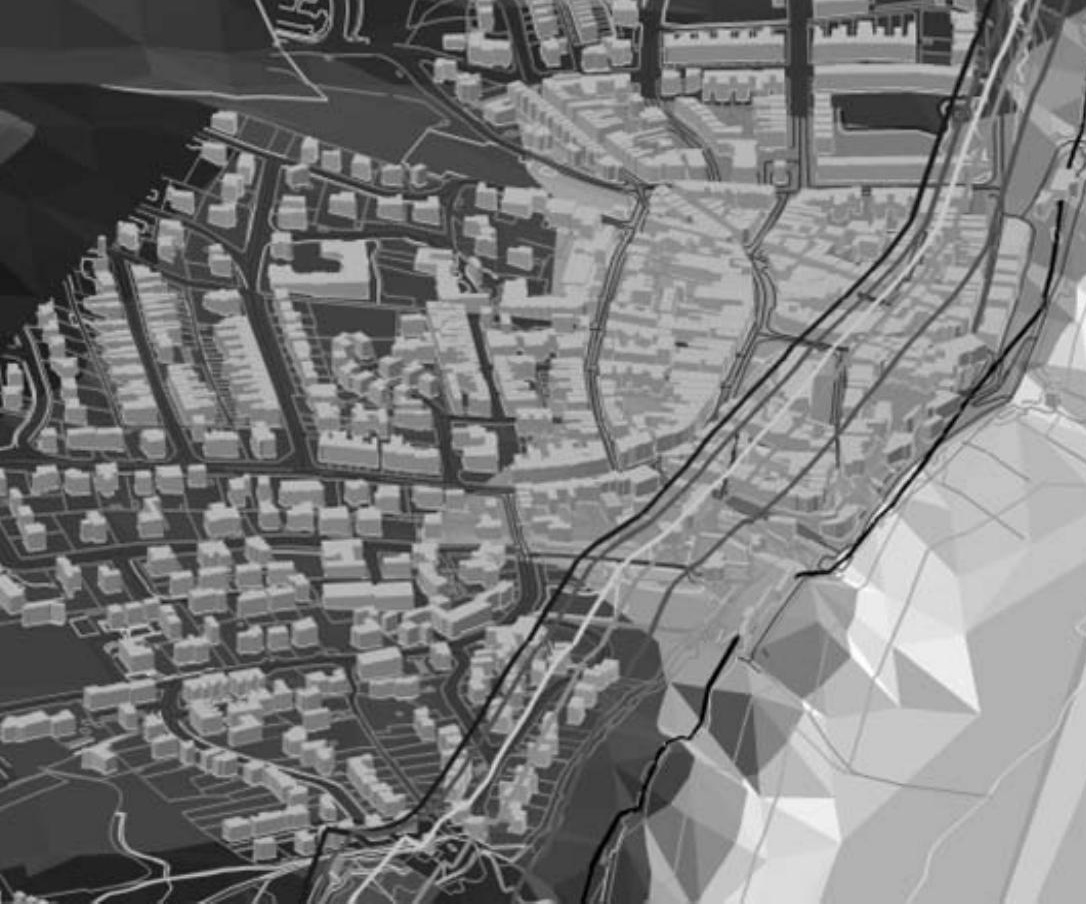